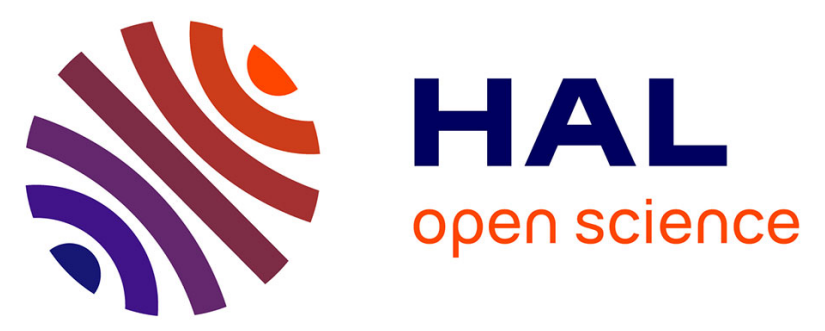

\title{
Stratigraphic and technological evidence from the middle palaeolithic- Châtelperronian-Aurignacian record at the Bordes-Fitte rockshelter (Roches d'Abilly site, Central France)
}

Thierry Aubry, Luca Antonio Dimuccio, Miguel Almeida, Jan-Pieter Buylaert, Laure Fontana, Thomas Higham, Morgane Liard, Andrew S. Murray, Maria João Neves, Jean-Baptiste Peyrouse, et al.

\section{- To cite this version:}

Thierry Aubry, Luca Antonio Dimuccio, Miguel Almeida, Jan-Pieter Buylaert, Laure Fontana, et al.. Stratigraphic and technological evidence from the middle palaeolithic- Châtelperronian-Aurignacian record at the Bordes-Fitte rockshelter (Roches d'Abilly site, Central France). Journal of Human Evolution, 2012, 62, pp.116-137. 10.1016/j.jhevol.2011.10.009 . hal-02538284

\author{
HAL Id: hal-02538284 \\ https://hal.science/hal-02538284
}

Submitted on 9 Apr 2020

HAL is a multi-disciplinary open access archive for the deposit and dissemination of scientific research documents, whether they are published or not. The documents may come from teaching and research institutions in France or abroad, or from public or private research centers.
L'archive ouverte pluridisciplinaire HAL, est destinée au dépôt et à la diffusion de documents scientifiques de niveau recherche, publiés ou non, émanant des établissements d'enseignement et de recherche français ou étrangers, des laboratoires publics ou privés. 


\title{
Stratigraphic and technological evidence from the middle palaeolithic- Châtelperronian-Aurignacian record at the Bordes-Fitte rockshelter (Roches d'Abilly site, Central France)
}

\author{
Thierry Aubry $^{\mathrm{a}, *}$, Luca Antonio Dimuccio ${ }^{\mathrm{b}, \mathrm{c}}$, Miguel Almeida ${ }^{\mathrm{d}}$, Jan-Pieter Buylaert ${ }^{\mathrm{e}, \mathrm{i}}$, Laure Fontana ${ }^{\mathrm{f}}$, \\ Thomas Higham $^{\mathrm{g}}$, Morgane Liard ${ }^{\mathrm{h}}$, Andrew S. Murray ${ }^{\mathrm{i}}$, Maria João Neves ${ }^{\mathrm{d}, \mathrm{k}}$, Jean-Baptiste Peyrouse ${ }^{\mathrm{j}}$, \\ Bertrand Walter ${ }^{\mathrm{j}}$

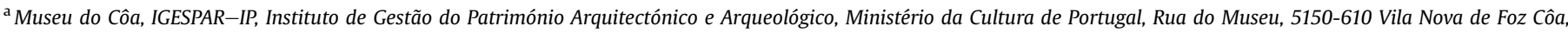 \\ Portugal \\ ${ }^{\mathrm{b}}$ Centro de Estudos de Geografia e Ordenamento do Território (CEGOT), Faculdade de Letras, Universidade de Coimbra, Praça da Porta Férrea, $3004-530$ Coimbra, Portugal \\ ${ }^{c}$ Departamento de Ciências da Terra, Faculdade de Ciências e Tecnologia, Universidade de Coimbra, Largo Marquês de Pombal, $3000-272$ Coimbra, Portugal \\ d Dryas Octopetala/iDryas, Rua Aníbal de Lima, 170, 3000-030 Coimbra, Portugal \\ ${ }^{\mathrm{e}}$ Radiation Research Division, Risø DTU, DK-4000 Roskilde, Denmark \\ ${ }^{\mathrm{f}}$ CNRS, UMR 7041, Maison de l'Archéologie et de l'Ethnologie R. Ginouvès, 21, Allée de l'Université, 92023 Nanterre cedex, France \\ ${ }^{g}$ Oxford Radiocarbon Accelerator Unit, RLAHA, University of Oxford, United Kingdom \\ ${ }^{\mathrm{h}}$ UMR 6042 GEOLAB, INRAP-Direction interrégionale Centre/Île-de-France, Base Orléans, France \\ ${ }^{\mathrm{i}}$ Nordic Laboratory for Luminescence Dating, Department of Earth Sciences, Aarhus University, Risø DTU, DK-4000 Roskilde, Denmark \\ ${ }^{j}$ Société d'Études et de Recherche sur le Paléolithique de la Vallée de la Claise, Les Chirons, 37290 Preuilly-sur-Claise, France \\ ${ }^{\mathrm{k}}$ CIAS - Centro de Investigação em Antropologia e Saúde - Departamento de Ciências da Vida, Faculdade de Ciências e Tecnologia, Universidade de Coimbra, \\ Apartado 3046, 3001-401 Coimbra, Portugal
}

\section{A R T I C L E I N F O}

\section{Article history:}

Received 3 January 2011

Accepted 19 October 2011

\section{Keywords:}

Middle/upper Palaeolithic transition

Archaeo-stratigraphy

Geoarchaeology

Radiocarbon and luminescence dating

France

Anatomically modern humans

Neanderthal

\begin{abstract}
A B S T R A C T
This paper presents a geoarchaeological study of Middle and Upper Palaeolithic (Châtelperronian, Aurignacian and Solutrean) occupations preserved at the Bordes-Fitte rockshelter in Central France. The lithostratigraphic sequence is composed of near-surface sedimentary facies with vertical and lateral variations, in a context dominated by run-off and gravitational sedimentary processes. Field description and micromorphological analysis permit us to reconstruct several episodes of sediment slope-wash and endokarst dynamics, with hiatuses and erosional phases. The archaeostratigraphic succession includes Châtelperronian artefacts, inter-stratified between Middle Palaeolithic and Aurignacian occupations. Systematic refitting and spatial analysis reveal that the Châtelperronian point production and flake blanks retouched into denticulates, all recovered in the same stratigraphic unit, result from distinct and successive occupations and are not a 'transitional' Middle to Upper Palaeolithic assemblage. The ages obtained by ${ }^{14} \mathrm{C}$ place the Châtelperronian occupation in the $41-48 \mathrm{ka}$ cal BP (calibrated thousands of years before present) interval and are consistent with the quartz optically stimulated luminescence age of $39 \pm 2 \mathrm{ka}$ and feldspar infra-red stimulated luminescence age of $45 \pm 2 \mathrm{ka}$ of the sediments. The Bordes-Fitte rockshelter sequence represents an important contribution to the debate about the characterization and timing of the Châtelperronian, as well as its affinities to earlier and later industries.
\end{abstract}

(C)

\footnotetext{
Corresponding author.

E-mail addresses: thaubry@sapo.pt (T. Aubry), luca@ci.uc.pt (L.A. Dimuccio), miguel.almeida@dryas.pt (M. Almeida), jabu@risoe.dtu.dk (J.-P. Buylaert), laure.fontana@mae.u-paris10.fr (L. Fontana), thomas.higham@rlaha.ox.ac.uk (T. Higham), morgane.liard@inrap.fr (M. Liard), anmu@risoe.dtu.dk (A.S. Murray), mjoao.neves@dryas.pt (M.J. Neves),jbpeyrouse@wanadoo.fr (J.-B. Peyrouse), bertrand.walter@wanadoo.fr (B. Walter).
}

\section{Introduction}

Until the discovery of the Saint-Césaire Neanderthal human remains in a stratigraphical unit yielding Châtelperronian lithic evidence (Lévêque and Vandermeersch, 1980; Vandermeersch, 1984), the Châtelperronian technocomplex was widely attributed to anatomically modern humans (AMH), based on the CombeCapelle burial stratigraphical attribution, and considered as the first phase of the Upper Palaeolithic (Peyrony, 1948; SonnevilleBordes, 1960, 1966; Bordes, 1968). 
Later, the attribution of the teeth found in levels X-VIII of the Grotte du Renne at Arcy-sur-Cure to Neanderthals by LeroiGourhan (1958) was based on a clear assessment of the Neanderthal morphological affinities of the teeth and of the temporal bone found in these levels (Hublin et al., 1996; Bailey and Hublin, 2006). Recently, the Combe-Capelle burial was directly dated by ${ }^{14} \mathrm{C}$ AMS to the Mesolithic (Hoffmann et al., 2011). The Neanderthal responsibility for the Châtelperronian culture is now widely accepted, with some notable exceptions (Bar-Yosef and Bordes, 2010). Furthermore, Bailey et al. (2009) suggest that AMH were the makers of all other Early Upper Palaeolithic technocomplexes and that the Châtelperronian is a 'transitional' phase. A direct ancestral relationship has been suggested between the Mousterian of Acheulean Tradition Type B and the Châtelperronian (Bordes, 1958; Harrold, 1989; Pelegrin, 1995; Pelegrin and Soressi, 2007), and the existence of transitional evolutionary phases has been proposed between these two technocomplexes (Lévêque, 1987).

The second main issue and related debate concerns the explanation of the cultural changes occurring in lithic and bone industries during the transition from the Middle to the Upper Paleolithic. In one model, this emergence pre-dated any evidence for the Aurignacian or modern humans in Europe and so the Châtelperronian could only be interpreted as representing the Neanderthals' independent transition to full cultural modernity (Zilhão, 2001, 2006, 2007; d'Errico, 2003). In a second model, the technological cultural changes in Western Eurasia resulted from an interaction between the Neanderthal and AMH (Demars and Hublin, 1989; Harrold, 1989; Mellars, 1989, 1999, 2005; Hublin, 1990; Djindjian et al., 2003). Such a model, based on the contemporaneity of the Châtelperronian with various forms of Aurignacian (Mellars, 2005), and the coincidence between the timing of the AMH dispersal and the technological and cultural changes, relies in large part on the chronological overlap of radiocarbon dates of bones recovered in occupations assigned by lithic evidence to these two groups. However, as noted by Mellars (2005), accuracy and precision of radiocarbon dates in the interval $30 \mathrm{ka}$ BP to $40 \mathrm{ka}$ BP are notoriously problematic (Conard and Bolus, 2003), and highly dependent on the bone pre-treatment protocol (Higham et al., 2006, 2009, 2010). The coexistence model has also been supported by stratigraphical, sedimentological and palynological correlations between cave and rockshelter sequences of Western (Lévêque and Miskovsky, 1987) and Eastern France (Leroyer and Leroi-Gourhan, 1983).

A second line of argument for the coexistence of the Châtelperronian and the Aurignacian in the acculturation model relies on the archaeological evidence of Aurignacian underlying Châtelperronian, observed at the Roc de Combe (Bordes and Labrot, 1967), Le Piage (Champagne and Espitalié, 1967) in Southern France and at El Pendo, in Northern Spain. However, the taphonomic reappraisal of these sequences, using refitting and spatial distribution of diagnostic lithic tool types, shows that the interstratifications do not correspond to an archaeological sequence and may be the result of post-depositional processes (Montes and Sanguino, 2001; Bordes, 2003). Gravina et al. (2005) have accepted the re-interpretation of these sites but have used 12 dates obtained by ultrafiltration protocol on bones from layers B5 to B1-3 of La Grotte des Fées (Châtelperron, Allier), and the typology of lithic and bone tools recovered in that sequence to support the coexistence of the Châtelperronian and Aurignacian (Gravina et al., 2005). Others (Zilhão and d'Errico, 2003; Zilhão et al., 2006) have suggested that all of the Châtelperronian ages younger than 36.5 ${ }^{14} \mathrm{C}$ ka BP obtained by classical AMS protocol are underestimated, and that the inter-stratified Châtelperronian/Aurignacian/Châtelperronian deposits reported by Henri Delporte at the Grotte des Fées are in fact 19th-century backfill and provide no support for interstratification. They consider that the overlap of radiocarbon dates between Châtelperronian and the earliest Aurignacian is a byproduct of imprecision and inaccuracy in the stratigraphic evidence and the radiocarbon dating (Zilhão and d'Errico, 2003; Zilhão et al., 2006).

Recent results obtained by palaeo-geneticists based on the analysis of the Neanderthal genome show that they are likely to have had a role in the genetic ancestry of present-day humans outside of Africa and that gene flow occurred between Neanderthals and modern humans (Green et al., 2010). This gene flow is explained by mixing of Neanderthals with early modern humans (ancestral to present-day non-African) in the Middle East prior to their expansion into Eurasia. These results did not bring evidence in favor of any of the two models to explain the cultural changes that have occurred around $40 \mathrm{ka}$ in south-western Eurasia. Such mixing is compatible with the archaeological record, which shows that Neanderthals came into contact with AMH in the Middle-East at least $80 \mathrm{ka}$ ago, whereas Neanderthals continued to exist in the same region after that time, probably until $50 \mathrm{ka}$ (Mercier and Valladas, 1994).

The differences in the interpretation of the archaeological evidence (Gravina et al., 2005; Zilhão et al., 2006) and of the archaeological association of the few human remains available for the $40 \mathrm{ka}-30$ ka period (Lévêque and Vandermeersch, 1980; Bailey et al., 2009; Bar-Yosef and Bordes, 2010) rely on: (1) different interpretations of the stratigraphic sequences and postdepositional processes; and (2) the dating methods used.

Thus, an improved scrutiny of the sedimentary processes, the systematic evaluation of the post-depositional evolution of human occupation levels (Zilhão et al., 2006, 2009; Texier, 2009; Aubry et al., 2010; Bertran et al., 2010), and more accurate and precise dating of the late Middle to Early Upper Palaeolithic (Higham et al., 2006) are crucial to the debate regarding Neanderthals, modern humans and their lithic and bone technologies. These objectives involve new dating (Higham et al., 2010) and reappraisal of material from old excavations (Bordes, 2003; Soressi, 2010), but new data and more stratified sequences are also necessary. The reconstruction of the sedimentary processes in cave or rockshelter context is a difficult task, particularly near the entrance where endokarstic and slope dynamics interfere. The Bordes-Fitte rockshelter record offers a new opportunity to establish the relationship between the human inputs and the natural processes that have sealed, eroded or altered the original spatial organization of the archaeological remains for the time interval during which the Middle to the Upper Palaeolithic transition took place.

\section{The Roches d'Abilly site}

The Roches d'Abilly site is located in Central France, along the Creuse Valley (Fig. 1), on the southern limit of the Touraine region, not far from Les Cottés (Pradel, 1961; Soressi et al., 2010) and La Fontenioux (Pradel, 1952), two sites preserved in caves of the Poitoux-Charentes cluster of the Châtelperronian distribution area (Lévêque, 1987; 1997; Pelegrin and Soressi, 2007; Bar-Yosef and Bordes, 2010). The Creuse Valley contains several Middle and Upper Palaeolithic occupation sequences conserved in caves, rockshelters, and open-air sites (Allain, 1976; Aubry et al., 2007).

The site is a complex of loci situated along a quarried escarpment at the right margin of the Creuse Valley, a cliff with a 300-mlong exposure of carbonate bedrock, in a geomorphological context quite distinct from most of the other sites that preserve the Middle to Upper Palaeolithic transition in south-western Eurasia. The discovery of lithic industries on the surface of the slope drew the attention of Jean-Baptiste Barreau to the site in 1925. In 1949, a collapsed rockshelter at the western end of the quarry (Fig. 2) was excavated and the results summarily published 
by Bordes and Fitte (1950). Seven layers were recognized; the second from the bottom was attributed to the Mousterian of Acheulean Tradition and the fourth to the Solutrean, although the lithic tools found in this last layer did not correspond completely to what was known for this industry. The authors suggested that "it can thus be a typologically mixed industry or a mixture of different industries" (Bordes and Fitte, 1950). This last hypothesis is not considered as the more parsimonious, but "only a wider excavation will make it possible to resolve this issue" (Bordes and Fitte, 1950). In 1968, André Chollet carried out a survey to the east of Bordes and Fitte's excavation, but the lithic finds did not enable a secure diagnosis and the site was abandoned. In 1982, Jean-

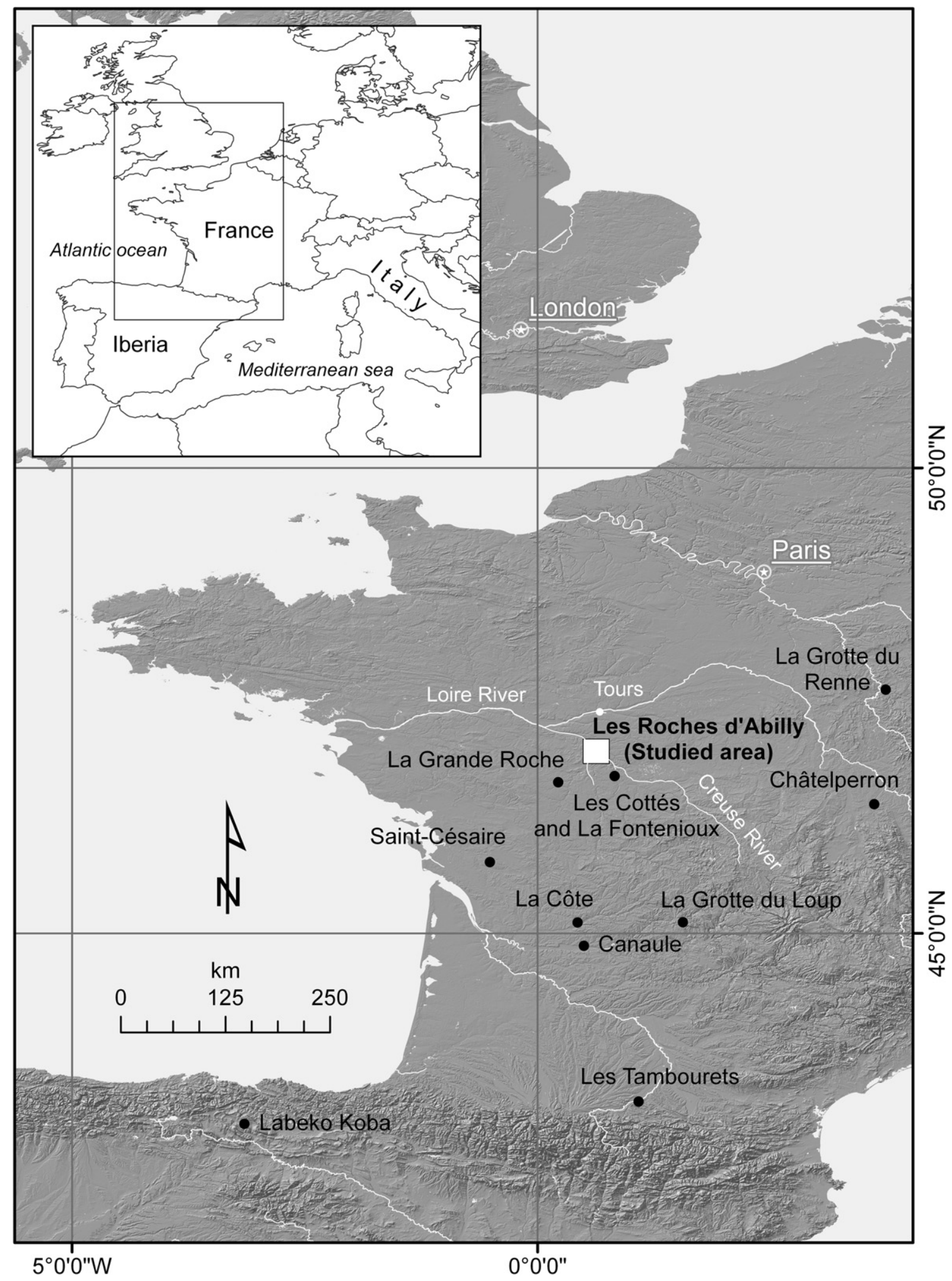

Figure 1. Location map of the Châtelperronian sites mentioned in the text and studied area. 

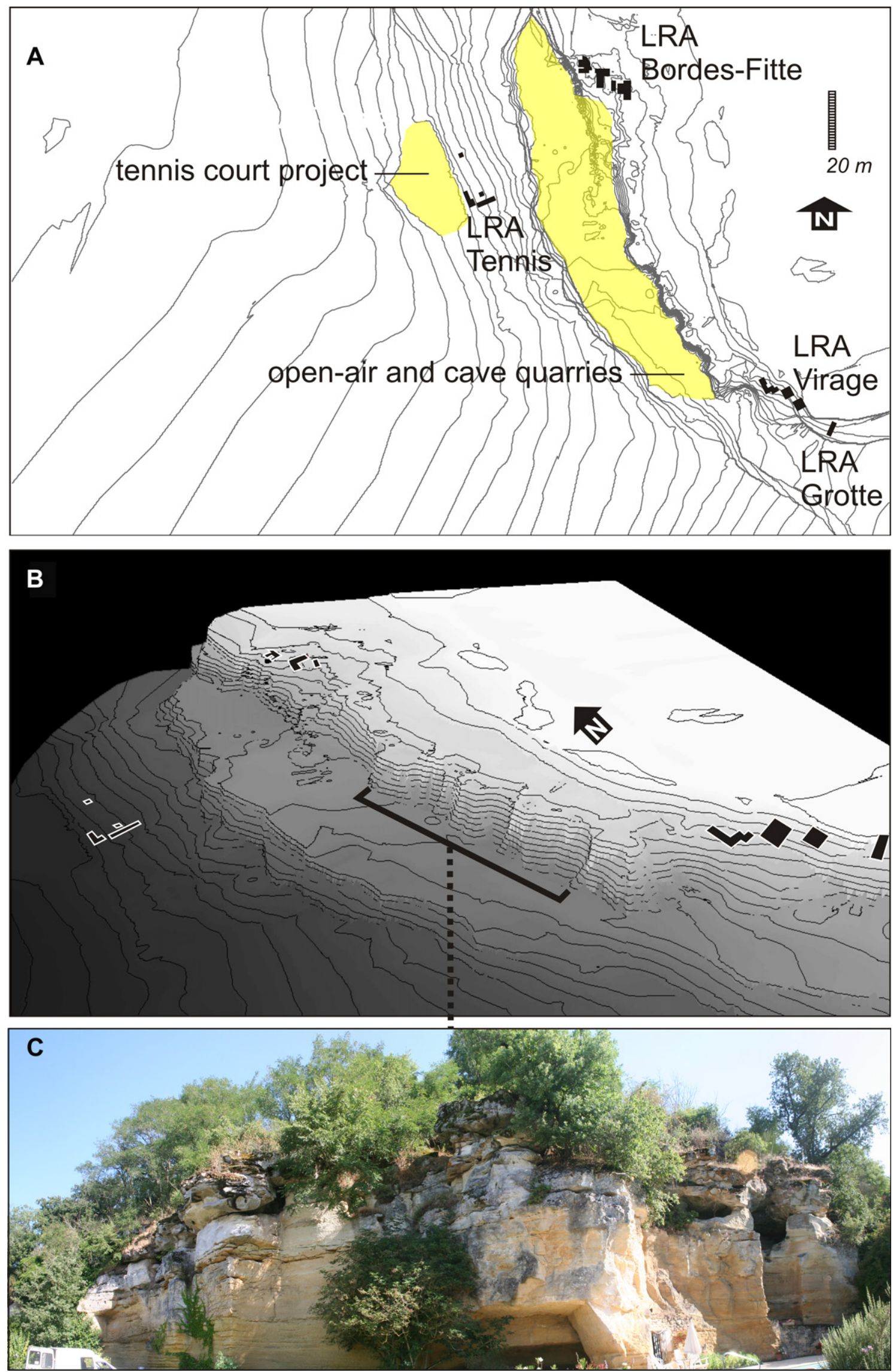

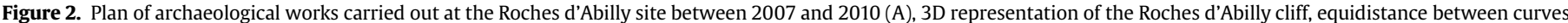
is $1 \mathrm{~m}(\mathrm{~B})$, portion of the outcrop exploited in open-air and cave quarries until the 19th century (C). 
Claude Marquet carried out a new test excavation near the Bordes and Fitte excavation but he was called to a halt by the presence of large and thick slabs of calcarenite, corresponding to the collapsed roofs of other rockshelters.

In 2007, we initiated new archaeological investigations, almost $2 \mathrm{~m}$ from the Bordes-Fitte excavation's eastern limit and $4 \mathrm{~m}$ from the section published in 1950 (see Fig. 1 in Bordes and Fitte, 1950) as well as at other locations along the ca. $300 \mathrm{~m}$ long cliff (Fig. 2A). Using explosives, we were able to remove the large collapsed slabs of compact calcarenite and access the underlying, intact Palaeolithic deposits. The data presented in this article only concern the Bordes-Fitte rockshelter.

\section{Materials and methods}

\section{Geoarchaeological approach}

The information presented is derived from stratigraphic, archaeological, and chronological data collected using standard geoarchaeological field approaches, including geomorphological and geological study of the site surroundings (Fig. 3A), sedimentological description of carbonate bedrock sections (Fig. 3B), description and stratigraphic correlation of the rockshelter siliciclastic deposits (Figs. 4 and 5), sampling for micromorphological analysis and radiometric dating. Field work included the systematic description of exposed cross-sections and profiles to reconstruct stratigraphic events, their vertical and lateral variations and a description of archaeological remains (Table 1). The description was made using a comprehensive form addressing the sedimentary, pedogenic and anthropogenic characteristics of the deposits (e.g., Keeley and Macphail, 1981; FAO-Isric, 1990) to collect the data necessary to assess issues of site formation processes. Geoarchaeological field units (hereafter GFU) were identified on the basis of lithostratigraphic, pedological and archaeological criteria and used as field categories. The field units were later grouped into geoarchaeological complexes (hereafter GC), taking into consideration only major changes in the depositional style, as well as major unconformities that would imply erosional phases or long hiatuses (details in Angelucci, 2002).

The field descriptions were supplemented with micromorphological observations (Table 1). The aim of this analysis was to support the field observation in order to document the formation processes operating at the site. Samples from the GFU E and GFU F were collected as undisturbed blocks cut. Thin sections were prepared by the Thomas Beckmann Laboratory (Germany) and observed under a polarizing microscope (Zeiss) with $2.5 \times, 10 \times$ and $40 \times$ magnifications, using plane-polarized light (PPL), crosspolarized light (XPL), and oblique incident light (OIL). Description of the thin sections follows the guidelines proposed by Bullock et al. (1985; modified by Stoops, 2003) and Courty et al. (1989).

\section{Analysis of archaeological remains}

The lithic assemblages were systematically studied for weathering and displacement damage (Table 1). The origin of the lithic raw material was determined by a macroscopical comparison with hand samples collected in the different geological formations of the Creuse and Cher River basins (Aubry, 1991). The characterization of non-local flint was complemented by a binocular examination of the micro-texture and of the fossil content following the petroarchaeological approach (Fernandes et al., 2008). The lithic remains were studied using a typo-technological approach, as proposed by Pelegrin (1995). In order to assess the sedimentary and post-depositional evolution processes (Goldberg and Macphail, 2006; Texier, 2009; Bertran et al., 2010), refitting was systematically tested, considering the stratigraphical relationship, spatial distribution, and scatter of refitted sets. The faunal remains were taxonomically studied and a total of 518 tooth fragments (ungulates: 463, carnivore: 55), recovered between 2007 and 2009, were systematically refitted or anatomically associated.

\section{Radiometric dating}

The chronological data (Tables 2 and 3) was obtained by Accelerator Mass Spectrometry (AMS) ${ }^{14} \mathrm{C}$ and Optically Stimulated Luminescence (OSL) dating, the latter using quartz and feldspar. Wood charcoal was found in the GC2 complex, but the material was poorly associated and too small for dating. Thus, all of the samples submitted for radiocarbon dating were of compact mammal bone identified to the species level. Table 2 lists the details of the bones dated and their provenance.

The Beta Analytic protocol of bone pre-treatment is collagen extraction with alkali. The bone samples dated at the Oxford Radiocarbon Accelerator Unit (ORAU) were based on chemical pre-treatment, target preparation and AMS measurement procedures outlined in previous publications (Higham et al., 2006; Brock et al., 2010a,b). Bone collagen was extracted from whole bone or tooth dentine using the manual Oxford method (Bronk Ramsey et al., 2004; Higham et al., 2006; Brock et al., 2010a,b), comprising a decalcification with $0.5 \mathrm{M} \mathrm{HCl}$, an $0.1 \mathrm{M}$ $\mathrm{NaOH}$ wash, then re-acidification using $0.5 \mathrm{M} \mathrm{HCl}$. Each step was interspersed with rinsing using distilled water. Gelatinization of the collagen was undertaken with weakly acidic $\mathrm{pH} 3$ water at $75{ }^{\circ} \mathrm{C}$ in an incubator for $20 \mathrm{~h}$. The supernatant was recovered using an EziFilter ${ }^{\mathrm{TM}}$. All samples were ultrafiltered using a Vivaspin $^{\mathrm{TM}} 30 \mathrm{kD}$ MWCO ultrafilter (see Bronk Ramsey et al., 2004; Higham et al., 2006). The $>30 \mathrm{kD}$ fraction was freezedried and weighed into pre-combusted tin capsules for combustion, graphitization and AMS measurement. All ages reported here are conventional radiocarbon ages BP (after Stuiver and Polach, 1977).

Calibrating dates in this early period has been fraught with difficulty and controversy, due to the lack of agreement between different records (Van der Plicht et al., 2004; Bronk Ramsey et al., 2006; Weninger and Jöris, 2008). The recent publication of the INTCAL09 curve, extending to 50 ka (Reimer et al., 2009), has provided us with an interim curve, and further iterations of this are expected in the future. We used OxCal v4.1 (Bronk Ramsey, 2009) with the 'INTCAL09' dataset (Reimer et al., 2009) for all calibration. All errors are 1-sigma (Table 2).

For luminescence dating, purified quartz and K-rich feldspar grains $(180-250 \mu \mathrm{m})$ were extracted from the sediment in the usual manner (Aitken, 1985; 1998). The dose in quartz was measured using $40 \mathrm{~s}$ blue light stimulation and detection in the UV (Hoya U-340), with $8 \mathrm{~mm}$ diameter monolayers of grains mounted on stainless steel discs and a SAR protocol (Murray and Wintle, 2000) with a preheat of $260{ }^{\circ} \mathrm{C}$ for $10 \mathrm{~s}$ and a cut-heat of $220^{\circ} \mathrm{C}$. An elevated temperature $\left(280^{\circ} \mathrm{C}\right) 40 \mathrm{~s}$ blue light stimulation was inserted after every SAR cycle (Murray and Wintle, 2003). The usual laboratory tests were undertaken to confirm the appropriateness of the protocol (recycling, recuperation). The initial $0.8 \mathrm{~s}$ of the signal minus an early background (interval $4.6 s-5.4 s$ ) was used for all calculations. The dose in feldspar was measured using infra-red (IR) stimulation and detection in a blue-violet window (Schott BG39/Corning7-59 filters) with $2 \mathrm{~mm}$ diameter grain monolayers in stainless steel cups. A postIR IR SAR protocol (Thomsen et al., 2008; Buylaert et al., 2009; Thiel et al., 2011) was used with a $60 \mathrm{~s} 320{ }^{\circ} \mathrm{C}$ preheat, first IR 


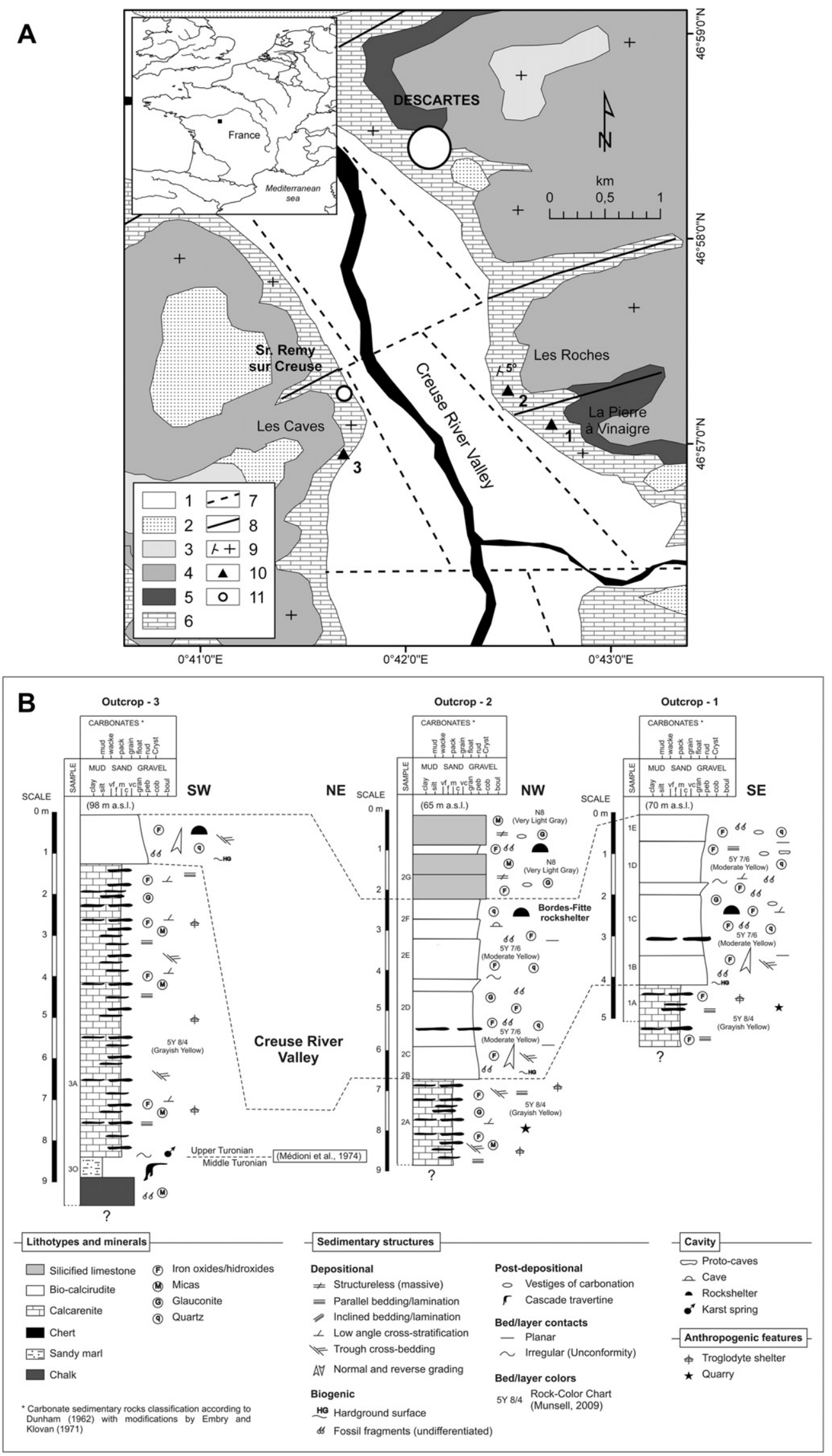

Figure 3. Geological setting of the Roches d'Abilly site and surrounding area. (A) Geological map of the studied area adapted from Médioni et al. (1974). Modern siliciclastic alluvial deposits (1), ancient siliciclastic alluvial deposits (2), Mio-Pliocene siliciclastic cherty mud deposits (3), Eocene siliciclastic cherty mud deposits and lacustrine marl and limestone (4), Upper Cretaceous sand and clay with spongolite and chert (5), Late Cretaceous (Turonian) chalk and calcareous tufa, sandy marls, clastic cherty limestone (bio-calcirudite and calcarenite) and silicified limestone (6), uncertain tectonic line (7), fault (8), strike and slip, and horizontal bedding (9), described outcrop (10), urban place (11). (B) Upper Turonian calcareous bedrock synthetic log's from three outcrops showing the sedimentary sequence and the Bordes-Fittes rockshelter stratigraphic position. 
stimulation at $50{ }^{\circ} \mathrm{C}(200 \mathrm{~s})$ and the second stimulation (200 s) at $290{ }^{\circ} \mathrm{C}$ and a high-temperature $\left(325^{\circ} \mathrm{C}\right)$ IR exposure (200 s) after each SAR cycle. Thiel et al. (2011), Thomsen et al. (2011) and Buylaert et al. (submitted for publication) have shown that this post-IR IR signal is stable, i.e., anomalous fading (Spooner, 1994) is not detectable. Calculations were made using the initial $2 \mathrm{~s}$ of the post-IR IRSL decay curve minus a background derived from the last $50 \mathrm{~s}$.

Dose rates were determined using high-resolution gamma spectrometry (Murray et al., 1987) and the conversion factors of Olley et al. (1996). For K-feldspar extracts the internal beta dose rate of ${ }^{40} \mathrm{~K}$ was calculated assuming an effective $\mathrm{K}$ concentration of $12.5 \pm 0.5 \%$ (Huntley and Baril, 1997).

\section{Bioanthropology}

The terms used to describe the single human tooth recovered follow those of Hillson (2003), and metrics were obtained according to the recommendations of Olivier and Demoulin (1990). Dental developmental age determination is based on Hillson (2003). Nonmetric data were recorded according to ASUDAS system (Turner et al., 1991). Tooth wear was scored on the basis of dentine exposure surfaces, following Smith (1984).

\section{Regional geological and geomorphological settings}

Located in the Touraine region, on the south-western margin of the Paris Basin (Mégnien et al., 1980; Guillocheau et al., 2000; Dercourt, 2002), near the confluence of the Claise River with the Creuse River (a tributary of the Vienne River which joins the Loire Valley on its left-bank downstream of Tours; Fig. 1), the study area corresponds to a karstic plateau modeled in Cretaceous rocks (Nicod, 2002), often covered by Cenozoic deposits. According to Campy et al. (1994), the study area is a weakly karstic zone. Locally, the karstic plateau is cut by the Creuse River Valley, a wide and relatively flat alluvial plain delimited by $15-\mathrm{m}$-high cliffs on both banks. The right bank also shows a gentler slope at the boundary between the cliff and the alluvial plain (Fig. 3A).

Where the Creuse River enters in the Paris Basin (Médioni et al., 1974; Dercourt, 2002; Larue, 2008), to the south of the study area, the valley widens, the fluvial terraces become numerous and the alluvial deposits thicken (Voinchet et al., 2010). The drainage network was developed according to the main tectonic structures of the region, with NNW-SSE, ENE-WSW and E-W directions (Fig. 3A). The bedrock exposed along the Roches d'Abilly cliff is composed by an Upper Cretaceous (Upper Turonian) lithostratigraphic succession of chalk, calcareous tufa with few nodular chert, sandy marl, and alternating clastic limestone (bio-calcirudite and calcarenite affected by decalcification, and silicification), with thin chert bands, and very compact silicified limestone on the top (Médioni et al., 1974). These lithostratigraphic units were observed and described in three distinct outcrops on both sides of the valley (Fig. 3B). Regionally, decalcification of the Upper Turonian unit and secondary silicification processes have provided abundant large nodules of a high-quality flint used during all of the prehistory.

The Cenozoic sediments lay on the Turonian carbonate rocks. This sedimentary cover includes Eocene cherty mudstone and lacustrine marls and limestone, Mio-Pliocene formations of mudstone units that overlie the Eocene deposits in some locations, and Quaternary alluvial deposits with some quartz and flint pebbles (Fig. 3A).

During the final episode of Upper Cretaceous sub-aerial exposure, and throughout to Quaternary times, the carbonate bedrock was affected by important weathering processes, such as dissolution (Laignel et al., 1999), silicification, ferruginization, and freee-thaw. The dissolution and freeze-thaw mechanisms were responsible for the development of an important secondary porosity, resulting in the development of horizontal inter-bedded caves and rockshelters (Fig. 3B). Most of these caves and rockshelters were subsequently filled by siliciclastic and carbonate sediments (e.g., Bordes-Fitte rockshelter), and are privileged environments where archaeological sediments and features were preserved.

\section{Formation processes at the Bordes-Fitte rockshelter}

\section{Stratigraphic record and sedimentary sources}

The geoarchaeological field description and the micromorphological analysis of the Bordes-Fitte rockshelter filling are given in Table 1 . The lithostratigraphic sequence was divided into eight field units (GFU $A \div \mathrm{H}$ ), later grouped into six geoarchaeological complexes (GC $1 \div 6$ ) separated by four main disconformities and two non-depositional unconformities (Figs. 4 and 5). Stratigraphic analysis shows that the deposit's geometry is strongly adapted to the rockshelter morphology, with irregular bedding and significant lateral variations (in the quantity and size of gravels, the grain size distribution and the presence/absence of some units) due to the multiple origins of the inputs and the different nature of the involved sedimentary processes described later. Other factors, such as the quantity of burrows (both rodents and insects) are related to near-surface conditions.

From the geometry of the sediments in the Bordes-Fitte rockshelter, it is clear that inputs are related to the lithology of the incised Cenozoic overlying units (through their sub-aerial erosion and endokarstic and/or down-slope transport and redeposition), coupled with weathering of the carbonate bedrock (Table 1, Figs. 4 and 5). As indicated by the common presence of quartz grains, the ultimate origin of the siliciclastic fraction is the widespread MioPleistocene detrital units found lying on the Upper Cretaceous bedrock, (Table 1 and Fig. 3A). The clay and silt inputs, however, are probably also derived from the erosion of earlier Eocene units and of pre-existing rockshelter sediments. Chemical weathering processes cannot be excluded in the formation of part of this fine fraction.

Carbonate rock fragments, with various sizes, are present throughout the geoarchaeological sequence (Fig. 5). The origin of these rocky carbonate fragments most probably resides in the normal processes of mechanical degradation of the roof and walls of the rockshelter, as indicated by their heterometry and varied shape. However, it cannot be excluded that some of the carbonate rock fragments with smaller size (clasts $2 \div 4 \mathrm{~cm}$ ) correspond to rock fragments brought into the shelter from the outside, or are related to freeze-thaw weathering of the roof and walls of the rockshelter followed by short-distance displacement by rapid water flows (Table 1 and Fig. ).

Periglacial features or freeze-thaw impact have not been observed at the macroscopic observation scale.

Only GC4 and GC5 complexes have been studied at a microscopic scale. There is no clear evidence of frost impact and freeze-thaw action in the GC 4 complex. The lenticular beddings observed are probably not the result of segregated ice action (ice lensing formation) but were sorted by water (alluvial context of the sedimentation). The silt and clay capping on the top of free grains is due to leaching, which confirms water circulation in the sediment, perhaps in a periglacial context. In the GC 5 complex, observation of vertical orientation of micaflakes and porosity (elongated and vertical) could be attributed to frost impact (frost jacking process), but this is not entirely clear and cannot be confirmed. 


\section{Sedimentary dynamics}

The formation of the rockshelter is due to concomitant factors that include: i) the alternation in the Late Cretaceous carbonate bedrock of relatively soft beds (bio-calcirudite and calcarenite) and harder silicified limestone (roof of the shelter); ii) water circulation into the bedrock with intercalated phases of erosion and accumulation of sediments; iii) and possibly, once the shelter had became a moist microenvironment, frost action along the shelter's backwall could take place.

After the opening of the rockshelter, the weathering of the carbonate bedrock started (GC1 complex) and perhaps continued throughout via infilling through cryptocorrosion processes (carbonate alteration developed under a siliciclastic sedimentary cover according to Nicod, 1994). The formation of the GC2 complex is mainly related to an alluvial environment with some lacustrine characteristics, as expressed by grain size, texture and sedimentary features (Table 1 and Fig. 5). After the deposition of the GC2 complex, there is a phase of interruption in the sedimentation and a probable change in the climatic conditions, followed by the deposition of a slope sequence (GC3 complex), and a phase of roof collapse resulting in the accumulation of large boulders with volumes in the order of cubic meters at the interface between the GC3 and GC4 complexes (first breakdown event; Fig. 5). The

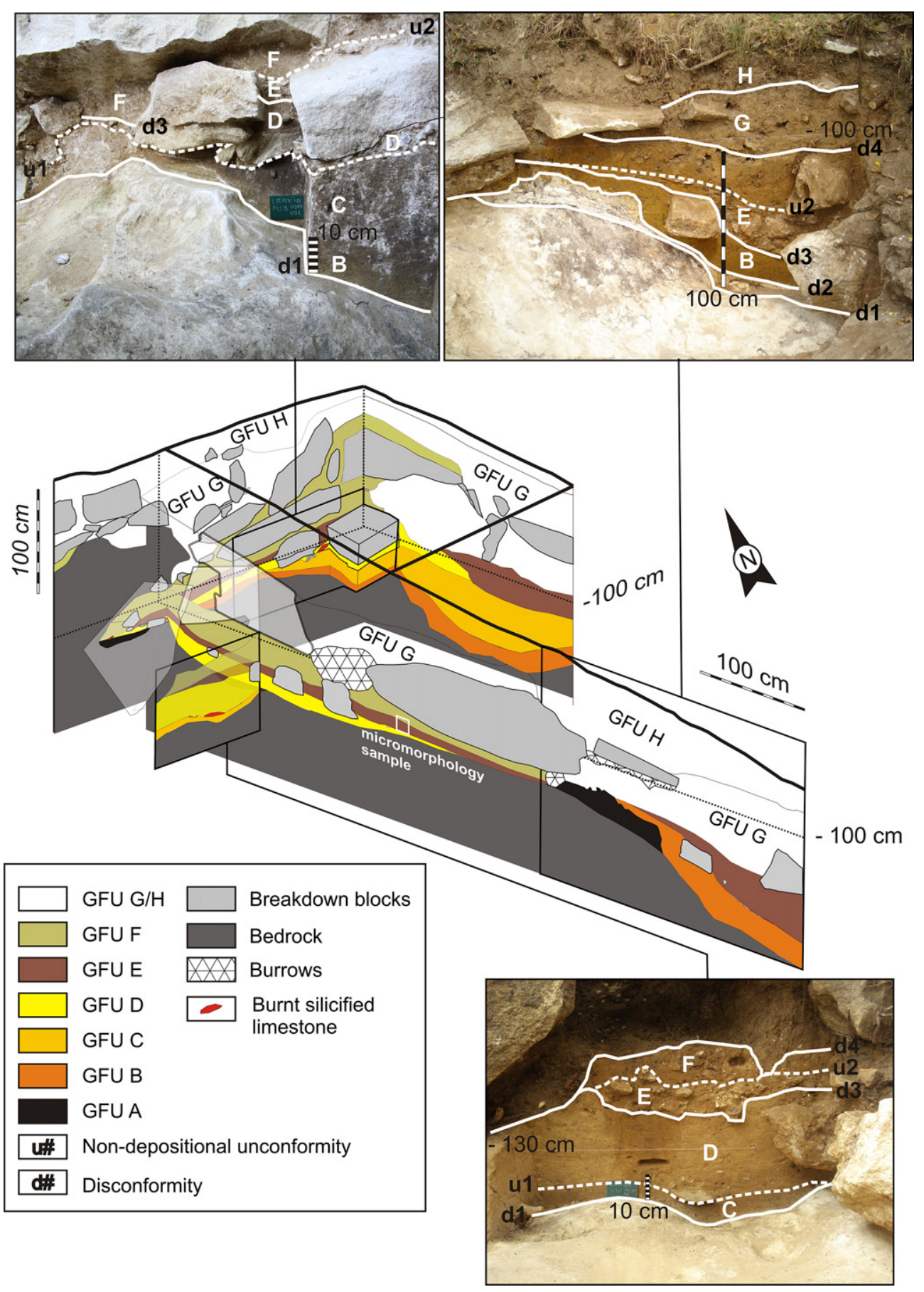

Figure 4. Schematic 3D representation of the lithostratigraphical sections observed during the excavation realized between 2007 and 2010 at the Bordes-Fitte rockshelter. 
interpretation of these breakdown events is not straightforward. It could indicate: 1) phases of decompression of the rock mass, which might depend on climatic factors, 2) seismic events, or 3) a rapid retreat of the cliff related to regional morphodynamic evolution. Around and under the, broken-down roof blocks, an erosional unconformity (disconformity), separates the top of GC3 complex from the overlying sequence represented by an alluvial channel-fill (GC4 and GC5 complexes).

The dynamics that led to the sedimentation of the upper part of the sequence (GC6 complex) were gravity-driven, with some concurrent action of water, and sedimentary input coming from the rockshelter wall and roof (second breakdown event; Fig. 5), and in part from the slope. Pedogenetic processes and anthropic disturbance with associated redeposition are evident.

\section{Lithic assemblages of the Bordes-Fitte sequence}

A Solutrean occupation of the shelter, proposed by Bordes and Fitte (1950) on the basis of the material recovered in their level 4, has been confirmed during the new excavations by the presence of bifacial shaping flakes, preforms and several small and large laurel-leaves in the GC5 complex and more rarely in the GC6 complex. An age of $19,020 \pm 110{ }^{14} \mathrm{C}$ yr BP (OxA-22315 - ca. 22,500 cal yr BP; Table 2) has been obtained from a red deer antler recovered in the GC5 complex, and the enclosing sediments were dated using OSL on the quartz fraction to $20.6 \pm 1.2 \mathrm{ka}$ and by IRSL on the feldspar fraction to $23.1 \pm 1.2 \mathrm{ka}$ (Fig. 5 and Table 3). However, the lithic assemblage recovered in the GC5 complex also includes: 1) large blades detached with an organic soft hammer following a prismatic unipolar operative scheme, 2) bladelets extracted from carinated burins (Fig. 6, no 11), 3) nosed-end- scraper cores, and 4) a single atypical busked burin. Such reduction sequences are unknown in the regional Upper Solutrean, in which technology is based on bipolar blade cores (Aubry et al., 2007), neither correspond to the Proto-solutrean and final Gravettian blade production (Klaric et al., 2009). Instead, they correspond to tool types and a blade technology characteristic of the Aurignacian (Sonneville-Bordes, 1960; Bon, 2002; Bordes, 2006b).

The underlying GC4 complex is interpreted sedimentologically and according to its micromorphological characteristics as a deposit in secondary position, yet it contains the majority of the faunal remains recovered in the rockshelter. The lithic assemblage is composed of two components that feature a distinct weathering stigma. The first component (representing around 10\% of the lithic assemblage in the uppermost $5 \mathrm{~cm}$ and $45 \%$ in the lower $5 \mathrm{~cm}$ ) is represented by pieces that are highly patinated, edge-damaged and altered by freeze-thaw, produced in the framework of a discoidal (Boëda, 1993; Peresani, 2003) and a recurrent unidirection Levallois method. The altered lithic assemblage, associated with siliciclastic gravels originating from the Cenozoic units overlying the site, is well sorted as indicated by the over-representation of the $1-5 \mathrm{~cm}$ fraction. The test excavations undertaken along the Roches d'Abilly cliff (Fig. 2A) have revealed that such altered lithic materials are systematically present in the slope deposits in secondary position. The unpatinated, fresh lithic second component of the GC4 complex displays some fragments of 'strangled' blades, and of blades and endscrapers with invasive scalariform retouch made on blanks extracted from unipolar prismatic cores (Fig. 6). Diagnostically Solutrean material is absent. A Dufour bladelet of the sub-type Dufour (Fig. 6, no 14) was recovered in association with bladelet production debris from nosed-scraper and carinated burin cores similar to those found

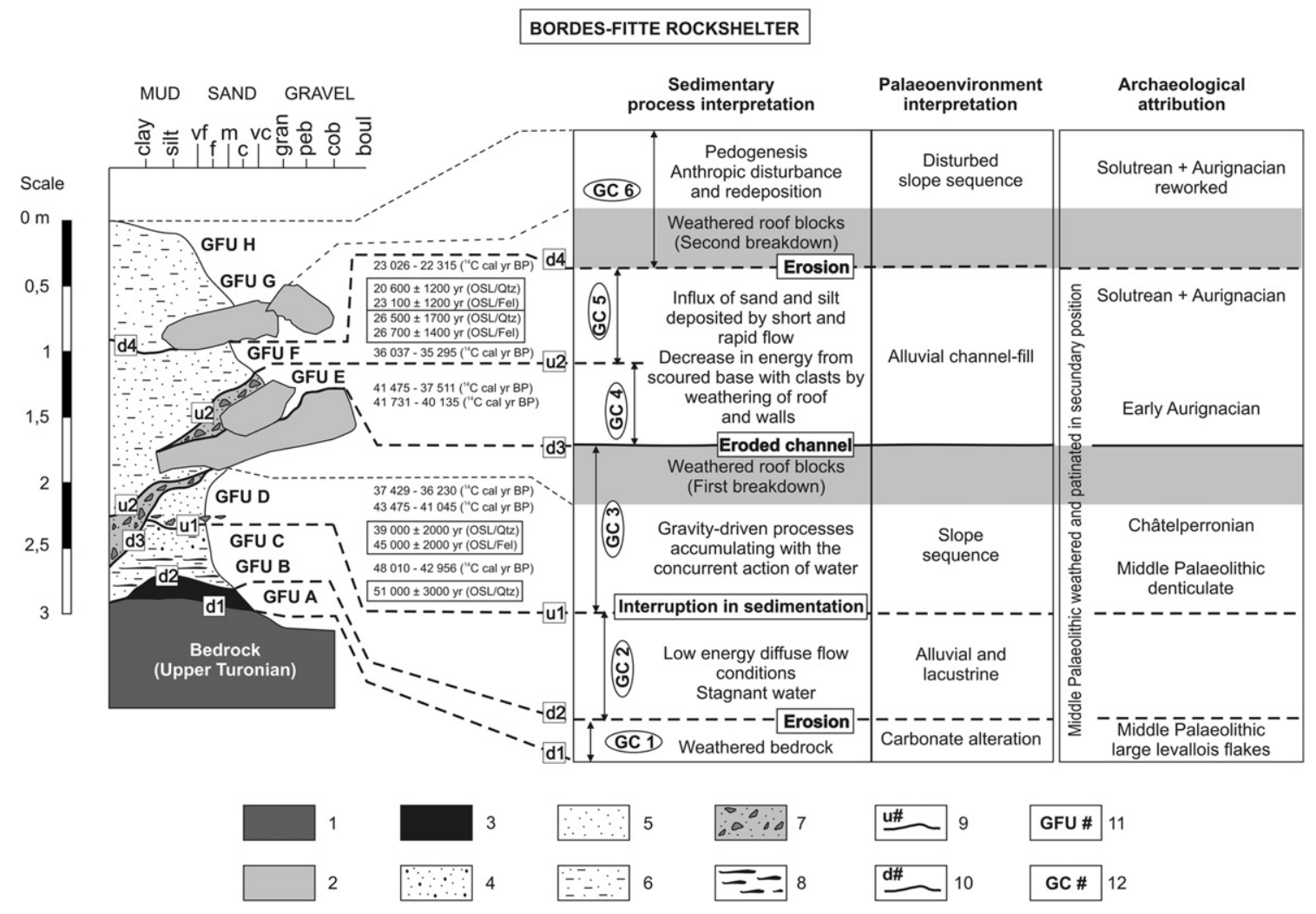

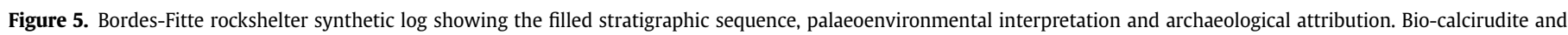

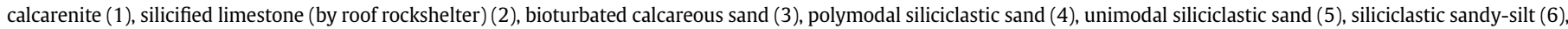

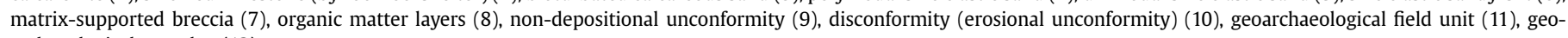
archaeological complex (12). 
Table 1

Field descriptions and micromorphological characteristics of the geoarchaeological field units (GFU), and geoarchaeological complexes (GC), in the Bordes-Fitte rockshelter. Spatial distribution, weathering and displacement damage description of the archaeological remains.

\begin{tabular}{|c|c|c|c|}
\hline GFU & GC & Field and micromorphological characteristics & $\begin{array}{l}\text { Archaeological material distribution } \\
\text { patterns and preservation stage }\end{array}$ \\
\hline $\mathrm{H}$ & 6 & $\begin{array}{l}\text { Grayish brown siliciclastic fine-medium sandy-loam with some angular and } \\
\text { subangular clasts ( } 2-4 \mathrm{~cm} \text { are the most represented range) of biocalcarenite } \\
\text { and blocks of silicified limestone (from the rockshelter roof), with random } \\
\text { distribution and orientation patterns. Bioturbation, pedogenesis (alfisols), } \\
\text { anthropic disturbance and redeposition, all intense. Drape geometry with a } \\
\text { depositional massive structure and granular texture. The predominant quartz } \\
\text { grains are angular and subangular, with high sphericity and moderately sorted. } \\
\text { The matrix is silt. The lower boundary is diffuse and poorly distinct. } \\
\text { Thickness is variable, reaching up to some } 30 \mathrm{~cm} \text {. }\end{array}$ & Archaeological material is rare. \\
\hline G & & $\begin{array}{l}\text { Moderate brown siliciclastic fine-medium sandy-loam with some angular } \\
\text { and subangular clasts ( } 2-4 \mathrm{~cm} \text { are the most represented range) of biocalcarenite } \\
\text { and some blocks of silicified limestone (from the rockshelter roof), } \\
\text { with random distribution and orientation patterns. Bioturbation, } \\
\text { pedogenesis (alfisols), anthropic disturbance and redeposition, all intense. } \\
\text { Drape geometry with a depositional massive structure. The predominant } \\
\text { quartz grains are angular and subangular, with highly spheric and } \\
\text { moderately sorted. The matrix is silt. The lower boundary is clear, } \\
\text { sharp and irregular (disconformity). Thickness is variable, } \\
\text { reaching up to some } 40 \mathrm{~cm} \text {. }\end{array}$ & $\begin{array}{l}\text { Archaeological material is rare and is the } \\
\text { result of reworking and redeposition of } \\
\text { archaeological remains of the GFU F. }\end{array}$ \\
\hline $\mathrm{F}$ & 5 & $\begin{array}{l}\text { Dark yellowish orange siliciclastic fine-medium sandy-silt. Minor bioturbation. } \\
\text { Ribbon channel geometry with some vague depositional trough } \\
\text { cross-lamination structure; also infiltrated below the rockshelter breakdown } \\
\text { roof blocks. The predominant quartz grains are angular and subangular, } \\
\text { with high sphericity and well sorted. The matrix is silt. The lower } \\
\text { boundary is clear, but separating units with low contrast (non-depositional } \\
\text { unconformity). Thickness is variable, reaching up to some } 30 \mathrm{~cm} \text {. } \\
\text { Micromorphology: basic components are } 90 \% \text { coarse silt and a } \\
\text { small proportion of fine sand. Abundant muscovite may correspond }\end{array}$ & $\begin{array}{l}\text { Archaeological material (lithic and faunal) } \\
\text { is numerous. Most of the lithic pieces present a } \\
\text { good edge and surface conservation, } \\
\text { and are not patinated. Materials do not } \\
\text { show a preferential orientation, the mean } \\
\text { inclination of elongated bone or lithic } \\
\text { fragment is of } 19^{\circ} \text { (from } 1^{\circ} \text { to } 54^{\circ} \text {, calculated } \\
\text { on } 25 \text { measurements) and are concentrated } \\
\text { at the bottom. }\end{array}$ \\
\hline
\end{tabular}

to transported micaflakes, or remnants of limestone weathering.

The microstructure reveal an apedal material, gefuric and porphyric fabric, and vesicular porosity elongated with vertical orientation.

Calcitic hypocoatings exists around the vesicular voids.

E $\quad 4$

Dark yellowish orange matrix-supported breccia with angular and subangular clasts $(2-4 \mathrm{~cm}$ are the most represented range) of biocalcarenite and silicified limestone, with some orientation and distributed along the lower boundary. Minor bioturbation. Ribbon channel geometry with some vague depositional trough cross-lamination structure. The sediment is also infiltrated below the rockshelter breakdown roof blocks. The matrix is silty-coarse-sand with predominant quartz grains, angular and subangular, with highly spheric and well sorted. The lower boundary is clear, sharp and irregular over GFU B, GFU C and GFU D (incised channel - disconformity). Thickness is variable, reaching up to some $20 \mathrm{~cm}$. Micromorphology: basic components are $60 \%$ fine and medium sand and $40 \%$ coarse sand and gravels. The gravels are bioclastic and silicified limestone. Muscovite is represented by micaflakes of alluvial origin. The microstructure reveal an apedal material with pellicular grain structure or compact grain structure, and chitonic fabric with silt coatings around grains. Textural pedofeatures have been observed: lenticular beddings (sorted grains), silt layer up and medium sand layer down and capping on the top of free grains (silt and sorted quartz).

D 3 Dark yellowish orange siliciclastic fine-medium sand with some angular and subangular fragments (clasts ranging $2-4 \mathrm{~cm}$ are the most represented range) of biocalcarenite with random distribution and orientation patterns. Without bioturbation. Wedge geometry. Some vague stratification, due to the presence of discontinuous thin laminae of white carbonate silt intercalations on the top (at the contact with the rockshelter breakdown roof blocks), is recognized. The predominant grains of quartz are angular and subangular with high sphericity and well sorted. The matrix is silt. The lower boundary is clear, but separating units with low contrast (non-depositional unconformity). Thickness is variable, reaching up to some $20 \mathrm{~cm}$.

C 2 Dark yellowish orange siliciclastic fine-coarse sandy-clay-silt. Moderate bioturbation. Lens geometry with a depositional massive structure. The quartz grains, dominant, are angular and subangular, with high sphericity and moderately sorted. The matrix is clay-silt. The lower boundary is diffuse and poorly distinct. Thickness is variable, reaching up to some $30 \mathrm{~cm}$. concentrations. Pond geometry filling some cavities of carbonate bedrock. The predominant quartz grains are angular and subangular, with high sphericity and well sorted. The matrix is silt. The lower boundary is clear, sharp and irregular over the bedrock or the GFU A (disconformity).

Thickness is variable, reaching up to some $15 \mathrm{~cm}$.

Archaeological material (faunal and lithic) is abundant. The lithic remains included two distinct components: one deeply patinated, edge and surface-damaged, weathered by possible freeze-thaw action; another with a good surface conservation and all the sizes represented. The elongated faunal and lithic remains do not show an orientation pattern and the mean inclination is of $16^{\circ}$ (from $1^{\circ}$ to $48^{\circ}$, calculated on 40 measurements).

Lithic and faunal archaeological material is disposed horizontally with no orientation pattern. Faunal materials are essentially long bone fragments end teeth. Most lithic remains present good surface and edge conditions and are not patinated, but some pieces show a low degree of rounding on the edges and surfaces; the pieces smaller than $5 \mathrm{~mm}$ are under-represented.

Archaeological material is absent.

Archaeological material is absent. 
Table 1 (continued)

\begin{tabular}{|c|c|c|c|}
\hline GFU & GC & Field and micromorphological characteristics & $\begin{array}{l}\text { Archaeological material distribution } \\
\text { patterns and preservation stage }\end{array}$ \\
\hline A & 1 & $\begin{array}{l}\text { White and very light gray calcareous sand with intense bioturbation. } \\
\text { Lobe geometry. The siliciclastic sand fraction is fine-medium and formed } \\
\text { of angular and subangular, with high sphericity, well sorted, predominantly } \\
\text { quartz grains. The matrix is white carbonate silt with some laminar and } \\
\text { nodular structure parallel to the lower boundary (at the contact with the } \\
\text { carbonate bedrock). The lower boundary is clear, sharp and irregular } \\
\text { (disconformity). Thickness is variable, reaching up to some } 20 \mathrm{~cm} \text {. }\end{array}$ & $\begin{array}{l}\text { Archaeological material is rare and } \\
\text { constituted by two components. } \\
\text { One component is deeply patinated, } \\
\text { edge and surface-damaged and weathered } \\
\text { by possible freeze-thaw action. The other } \\
\text { component represents large pieces } \\
\text { presenting good edge and surface } \\
\text { conservation and not patinated }\end{array}$ \\
\hline
\end{tabular}

in overlying GC5 complex. The typology of the single retouched bladelet found and its association with the large keeled blades, considered as typological markers of the Aurignacian I (Bordes, $2006 \mathrm{~b})$, are consistent with the ages of $34,520 \pm 850{ }^{14} \mathrm{C}$ yr BP and $35,770 \pm 380{ }^{14} \mathrm{C}$ yr BP $\left(41,475-37,511{ }^{14} \mathrm{C}\right.$ cal yr BP and $41,731-40,135{ }^{14} \mathrm{C}$ cal yr BP) obtained on two long bones fragments from the top and the bottom, respectively, of the GC4 complex. The absence of keeled blades in the GC5 complex, the higher frequency of carinated burin and the single busked burin core for the production of twisted and rectilinear bladelets at the bottom of GC5 complex suggest the presence of two distinct Aurignacian occupations of the site (Sonneville-Bordes, 1960; Bordes, 2006b). The result of $31,640 \pm 230{ }^{14} \mathrm{C}$ yr BP $\left(36,037-35,295{ }^{14} \mathrm{C}\right.$ cal yr BP) obtained for a long bone fragment collected at the contact between GC4 and GC5 complexes, is stratigraphically and chronometrically consistent with this hypothesis.

In the underlying GC3 complex, the highly patinated, rounded, edge-damaged and freeze-thaw-altered lithic component in secondary position represents ca. $50 \%$ of the total. In the unpatinated and fresh lithic component, we have identified a reduction sequence, the objective of which, we interpret, was to obtain small blades of rectilinear profile, corresponding to the blanks of the Châtelperronian points recovered at the site (10 fragments corresponding to six Châtelperronian points after refitting Fig. 7A, no 1 and 2). Refitting revealed that such small blades with a flat section were extracted from both prismatic (Fig. 7) and burin type cores (Fig. 8, no 3 and 4) using soft stone hammers. A few of the larger prismatic blades were retouched into end-scrapers (1) or truncated (4). These two reduction schemes (prismatic bidirectional with a preferential platform, and flake core) are very similar to those described for the Châtelperronian material from the sites of Roc de Combe, la Côte (Pelegrin, 1995), Canaule II (Bachellerie et al., 2008), Quinçay (Guilbaud, 1993; Roussel and Sorressi, 2010) and Arcy-surCure (Bodu, 1990; Gouedo, 1990; Connet, 2002). However, the use of successive disjointed reduction surfaces and the resulting triangular section of the prismatic cores observed at La Grande Roche à Quinçay (Roussel and Sorressi, 2010) is also present, although not systematically, and the intercalated production of large and small blades shown by refitting at the Bordes-Fitte rockshelter (Fig. 8-11, no $1-3$ ) has never been noted elsewhere. The refits that correspond to the small blade production include some pieces recovered at the bottom of the GC4 complex, in areas where the GC3 complex is not protected by roof collapse (Figs. 5, 11 and 12).

In the GC3 complex, unpatinated and fresh lithic components also include a flake production scheme corresponding to the discoidal method (Boëda, 1993; Peresani, 2003) and a recurrent centripetal, Levallois scheme. Some of these flakes have been modified into notches (Fig. 9, no 1-3), and a single example of convergent side-scraper was discovered (Fig. 9, no 7).

The oldest human occupation of the rockshelter is represented by a few large retouched Levallois flakes (Fig. 10) recovered in the depressions formed at the top of the Cretaceous bedrock inside the GC1 complex, where it is preserved (Fig. 5).

\section{Characterization of the human occupations}

The GC1 archeological assemblage, a total of 63 pieces, is mainly composed of highly patinated, rounded, edge-damaged and freeze-thaw-altered lithic in secondary position (43), and a few unpatinated and fresh large retouched Levallois flakes made of the Upper Turonian flint (20). The Levallois flakes (Fig. 10) were recovered at the bottom of the sequence directly on the bedrock The unpatinated component indicates that the production of the flakes on large preferential Levallois cores took place elsewhere.

The two distinct typo-technological groups of discoidal/Levallois method and Châtelperronian points present in the unpatinated and fresh lithic component recovered in the GC3 complex (436 pieces coordinated during field work from a total of 3497 pieces) are very different in terms of raw materials, phases of the represented operative scheme sequences and refitting success ratio. The Middle Palaeolithic technological component is made up of several varieties of Upper Turonian flints available locally (Aubry, 1991), some represented by a single piece. Nine pieces attest to the longdistance procurement of raw materials. The macroscopical and binocular comparison of their micro-texture and fossil content, with hand samples collected in central France (Aubry, 1991; Fontana et al., 2009), allow us to identify the presence of Lower Turonian flint, a fine-grained translucent flint of high-quality available in the Cher River Valley and its tributaries, $50 \mathrm{~km}$ to the north. The refitting of the diagnostically discoidal and centripetal Levallois components concerns only six pieces from three groups being refitted from a total of 52 coordinated pieces.

The Châtelperronian blade production differs in that it is made on Upper Turonian flint collected in the Bourdel River Valley $(5 \mathrm{~km}$ to the east) and locally, in fluvial terraces or in Tertiary units. Refits indicate the presence of remains corresponding to all production phases of the Châtelperronian points, except for the cores from which flake blanks were extracted. One refit of three pieces reveals two successive retouching fractures during the production of a Châtelperronian point (Fig. 7A, no 1) and other refits reveal that some of the blades corresponding to the Châteperronian point blanks are missing (Fig. 7B). The remains corresponding to the Châtelperronian point production sequences yielded a high refit ratio. For the three best represented flint categories, these refit ratios show 36 pieces from a total of 125 (Fig. 7A), 31 of 91 (Fig. 7B), and 19 of 42 pieces (45\%). The spatial pattern of refitting Châtelperronian lithic remains shows that the first collapse of the shelter is posterior to the deposition of GFU D (Figs. 5 and 11B), and some recurrent nonanthropogenic reorientation of the smallest remains, corresponding to the inclination of GFU D took place prior to the collapse of the shelter. The refitting of pieces from GFU D with others recovered into the GC4 complex is limited to the area not covered by the rockshelter roof fragments (Figs. 5 and 11B). The tooth refits involve longer distances and are similar in orientation to the Châtelperronian lithic refits (Fig. 11C). This result is consistent with the notion that, in areas not sealed by roof collapse, finds from the upper part of GFU D were removed during the erosional event preceding the deposition of GC4 
Table 2

Synthesis of the radiocarbon dates for the Bordes-Fitte rockshelter.

\begin{tabular}{|c|c|c|c|c|c|c|c|c|c|c|c|}
\hline Site & $\mathrm{GFU}^{\mathrm{a}}$ & $G C^{b}$ & Field reference & Lab code & $\begin{array}{l}\text { Dating } \\
\text { method }\end{array}$ & Material & $\begin{array}{c}\text { Material } \\
\text { pre-treatment }\end{array}$ & $\mathrm{N}(\%)$ & $\mathrm{d} 13 \mathrm{C}(\%)$ & Age (yr BP) & $\begin{array}{l}{ }^{14} \mathrm{C} \text { calibrated } \\
\text { age }(\text { cal yr BP })^{\mathrm{c}}\end{array}$ \\
\hline $\begin{array}{l}\text { Bordes-Fitte } \\
\text { rockshelter }\end{array}$ & $\mathrm{F}$ & 5 & $\begin{array}{l}\text { LRA } 09 \\
\text { P11B no } 192\end{array}$ & OxA-22315 & ${ }^{14} \mathrm{C}$ AMS & $\begin{array}{l}\text { Antler } \\
\text { (Cervus Elaphus) }\end{array}$ & Ultrafiltration & $1.30 \%$ & -18.25 & $19,020 \pm 110$ & $\begin{array}{l}23,284-23,077(12,2 \%) \\
23,026-22,315(83,2 \%)\end{array}$ \\
\hline $\begin{array}{l}\text { Bordes-Fitte } \\
\text { rockshelter }\end{array}$ & $\mathrm{F}$ & 5 & $\begin{array}{l}\text { LRA } 07 \\
\text { N9B no } 68\end{array}$ & Beta-234193 & ${ }^{14} \mathrm{C}$ AMS & Bone & $\begin{array}{l}\text { Collagen extraction } \\
\text { with alkali }\end{array}$ & & -20.1 & $31,640 \pm 230$ & $\begin{array}{l}36,650-36,078(47,6 \%) \\
36,037-35,295(47,8 \%)\end{array}$ \\
\hline $\begin{array}{l}\text { Bordes-Fitte } \\
\text { rockshelter }\end{array}$ & $\begin{array}{l}\text { E } \\
\text { (top) }\end{array}$ & 4 & $\begin{array}{l}\text { LRA } 08 \\
\text { N10B no } 387\end{array}$ & $\begin{array}{l}\text { Lyon-6920 } \\
\text { (SacA18936) }\end{array}$ & ${ }^{14} \mathrm{C}$ AMS & $\begin{array}{l}\text { Bone } \\
\text { (Rangifer tarandus) }\end{array}$ & Ultrafiltration & & -17.8 & $34,520 \pm 850$ & $41,475-37,511(95,4 \%)$ \\
\hline $\begin{array}{l}\text { Bordes-Fitte } \\
\text { rockshelter }\end{array}$ & $\begin{array}{l}\text { E } \\
\text { (bottom) }\end{array}$ & 4 & $\begin{array}{l}\text { LRA } 08 \\
\text { N10B no } 507\end{array}$ & Beta-249596 & ${ }^{14} \mathrm{C}$ AMS & $\begin{array}{l}\text { Bone } \\
\text { (Rangifer Tarandus) }\end{array}$ & $\begin{array}{l}\text { Collagen extraction } \\
\text { with alkali }\end{array}$ & & -20.2 & $35,770 \pm 380$ & $41,731-40,135(95,4 \%)$ \\
\hline $\begin{array}{l}\text { Bordes-Fitte } \\
\text { Rock-shelter }\end{array}$ & $\mathrm{D}$ & 3 & $\begin{array}{l}\text { LRA } 09 \\
\text { P11A no } 307\end{array}$ & OxA-22342 & ${ }^{14} \mathrm{C}$ AMS & $\begin{array}{l}\text { Tooth } \\
\text { (Equus Cabalus) }\end{array}$ & Ultrafiltration & $0.96 \%$ & -20.97 & $37,400 \pm 800$ & $43,475-41,045(95,4 \%)$ \\
\hline $\begin{array}{l}\text { Bordes-Fitte } \\
\text { rockshelter }\end{array}$ & $\mathrm{D}$ & 3 & $\begin{array}{l}\text { LRA } 09 \\
\text { P10B no } 155\end{array}$ & OxA-22316 & ${ }^{14} \mathrm{C}$ AMS & $\begin{array}{l}\text { Bone } \\
\text { (Rangifer Tarandus) }\end{array}$ & Ultrafiltration & $2.10 \%$ & -19.65 & $41,200 \pm 1300$ & $48,010-42,956(95,4 \%)$ \\
\hline $\begin{array}{l}\text { Bordes-Fitte } \\
\text { rockshelter }\end{array}$ & $\mathrm{D}$ & 3 & $\begin{array}{l}\text { LRA } 08 \\
\text { O10B no } 456\end{array}$ & Beta-249595 & ${ }^{14} \mathrm{C}$ AMS & $\begin{array}{l}\text { Bone } \\
\text { (Bovid) }\end{array}$ & $\begin{array}{l}\text { Collagen extraction } \\
\text { with alkali }\end{array}$ & & -20.4 & $32,110 \pm 280$ & $\begin{array}{l}37,429-36,230(90 \%), \\
35,912-35,606(5,4 \%)\end{array}$ \\
\hline
\end{tabular}

a Geoarchaeological field unit.

b Geoarchaeological complex.

c Calibration used OxCal v4.1.7 Bronk Ramsey (2009); r:5; Atmospheric data from Reimer et al. (2009). All errors are 1-sigma.

complex, along an erosion channel following the limits of the fragmented roof blocks (Figs. 4, 5, 11A and C).

The vertical projection of the refitted pieces and of those assigned to a techno-typological group (Fig. 12) indicates that the two distinct technological categories detected in the GFU D can be vertically discriminated, with the lithics corresponding to blade production systematically overlying those that relate to flake production. This vertical discrimination of the two technological groups is best observed in rows 12 to 8 of the grid (Figs. 3 and 12), where GFU D is thicker, due to topography and lateral variation of the sedimentological characteristics of the deposit (probably resulting from gravity-driven processes accumulating but with the concurrent action of water, as suggested by the orientated pattern of the refits between more distant pieces; Fig. 11B).

The very low success rate of lithic (Fig. 11A) and tooth fragment refitting (Fig. 11C) and the distances, confirm the secondary position of the GC4 complex remains, suggested by the geological data. Tooth refitting essentially correspond to fragments recovered in a restricted area of less than $100 \mathrm{~cm}^{2}$ spanning the entire thickness (almost $15 \mathrm{~cm}$ ) of the GC4 complex. A group of four fragments of the same tooth, recovered in the GC4 and GC5 complexes, reveals spatial relations over greater distances. The refits, spatial distribution and orientation patterns observed in the GC4 complex together suggest that the faunal and lithic remains of this unit were secondarily dispersed by run-off on the slope around the roof fragments representing the rockshelter collapse (Fig. 5 and Table 1). The concentration of refitted bladelets and small flakes corresponding to a typical Aurignacian nosed-core located in quadrant B of the N-10 square (Fig. 6, no 13, 15 and Fig. 11) reveals that the deposition of the GC4 complex filled the voids around and under the irregular lower surface of the collapsed roof slabs. The
Aurignacian lithic and faunal components, mixed with the highly patinated and weathered lithic remains technologically assigned to the Middle Palaeolithic preserved in the same GC4 complex, must have been removed from a shelter located higher on the cliff, whence it was displaced and redistributed by slope processes.

Long-distance procurement of Lower Turonian flint, attested in the Middle Palaeolithic denticulate component of GFU D, is also represented by some fragments of large retouched blade in the GC4 complex. In GC4 and GC5, a Tertiary, translucent fine-grained flint of the Vienne River Valley (30 km to the South) was used. A carinated-core for bladelet production from this material was found, as well as two fragments of retouched blades made on Bathonian jasper from the Creuse River basin (Aubry, 1991).

The spatial distribution of the Solutrean bifacial shaping flakes and foliate point fragments, made on Upper Turonian flint available less than $15 \mathrm{~km}$ away, surrounds the larger fragmented slabs of the rockshelter's roof collapse (Fig. 11A). The Solutrean lithic remains, only present in the GC5 complex, correspond to flaking activities occupying a more restricted area, and their distribution and refits indicate a lower degree of post-depositional degradation than the Aurignacian blade and bladelet production remains of the GC4 complex, despite a secondary remobilization process (Fig. 11A).

This interpretation of a secondary filling of the GC 5 complex is supported by OSL ages of $26.5 \pm 1.7 \mathrm{ka}$ on the quartz fraction and $26.7 \pm 1.4 \mathrm{ka}$ on feldspar fraction obtained for the sediments collected under a large collapse-slab (Table 3). Because feldspar is reset by daylight significantly more slowly than quartz (e.g., Godfrey-Smith et al., 1988; Fig. 8 in, Thomsen et al., 2008), a limited exposure of the deposit should result in a significant difference between feldspar and quartz ages. This is not the case for the samples collected in the GC5 complex, the quartz and feldspar

Table 3

Synthesis of luminescence (OSL) ages for the Bordes-Fitte rockshelter.

\begin{tabular}{|c|c|c|c|c|c|c|c|c|c|}
\hline GFU & Field reference & Lab code & Depth, cm & Mineral & Age, ka & Dose, Gy & (n) & Dose rate, Gy/ka & w.c. (\%) \\
\hline $\mathrm{D}$ & LRA 09 P10A S4 & 092201 & 200 & Quartz & $51 \pm 3$ & $131 \pm 3$ & 23 & $2.56 \pm 0.12$ & 2 \\
\hline \multirow[t]{2}{*}{$\mathrm{D}$} & LRA 09 P10A S1 & 092202 & 200 & Quartz & $39 \pm 2$ & $102 \pm 4$ & 36 & $2.62 \pm 0.12$ & 3 \\
\hline & LRA 09 P10A S1 & & & Feldspar & $45 \pm 2$ & $156 \pm 3$ & 8 & $3.47 \pm 0.13$ & 3 \\
\hline \multirow[t]{2}{*}{$\mathrm{F}$} & LRA 09 P12A S2 & 092203 & 170 & Quartz & $20.6 \pm 1.2$ & $71 \pm 2$ & 37 & $3.45 \pm 0.16$ & 4 \\
\hline & LRA 09 P12A S2 & & & Feldspar & $23.1 \pm 1.2$ & $100 \pm 2$ & 9 & $4.30 \pm 0.17$ & 4 \\
\hline \multirow[t]{2}{*}{$\mathrm{F}$} & LRA 09 N11A S3 & 092204 & 150 & Quartz & $26.5 \pm 1.7$ & $74 \pm 3$ & 32 & $2.79 \pm 0.13$ & 1 \\
\hline & LRA 09 N11A S3 & & & Feldspar & $26.7 \pm 1.4$ & $97 \pm 3$ & 9 & $3.64 \pm 0.14$ & 1 \\
\hline
\end{tabular}

Note: (n) denotes the number of aliquots contributing to the dose. 

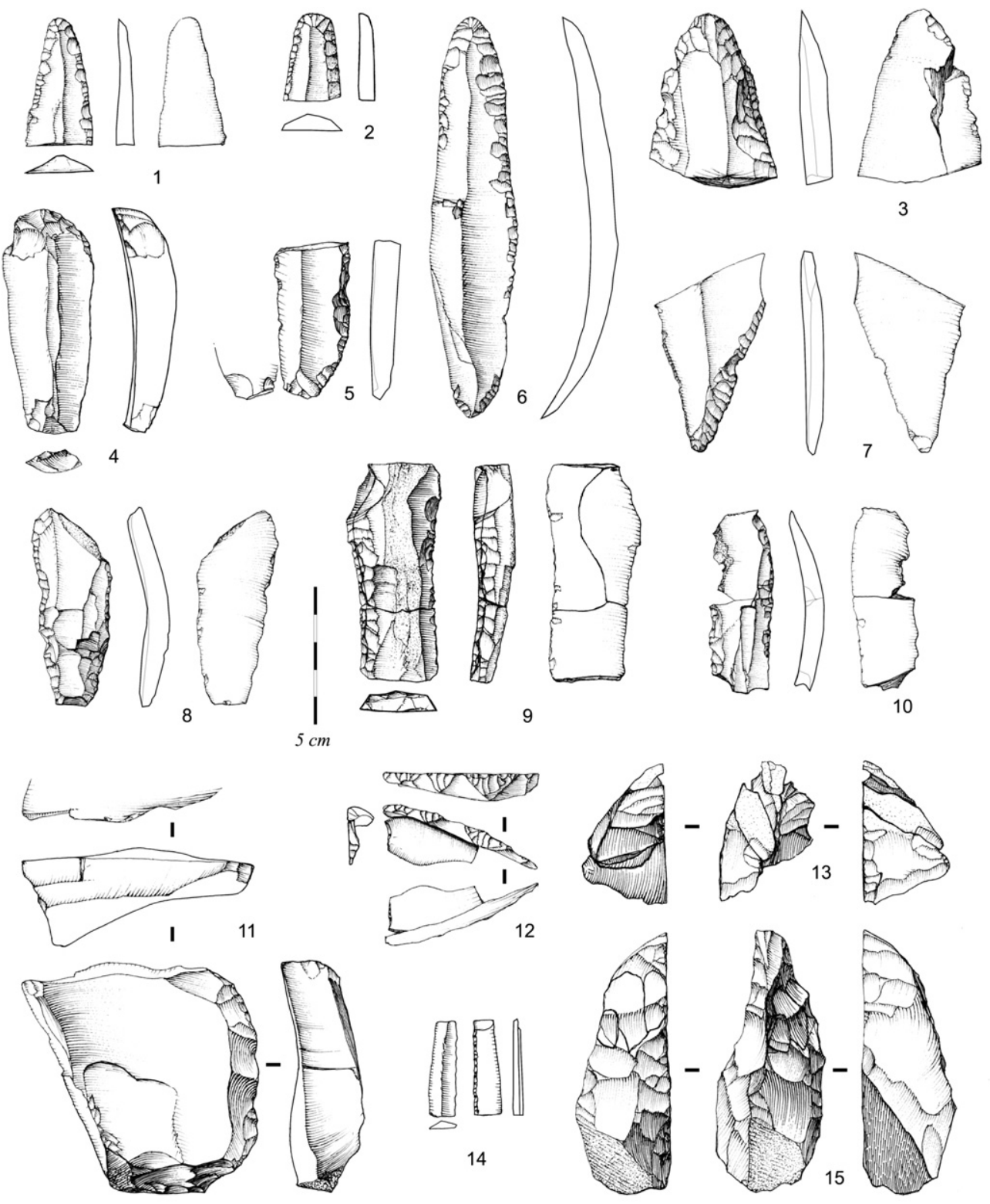

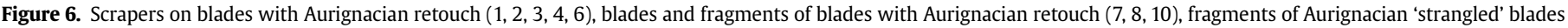
$(5,8)$, Dufour (sub-type Dufour) retouched bladelet (14), bladelet production sequence on keeled cores $(11,12,13,15)$ from GFU E $(1-10,12-16)$ and GFU F (11).

ages being indistinguishable (the equivalent doses, dose rates and luminescence ages for quartz and feldspar are summarized in Table 3) and, in addition, consistent with the over- and underlying radiocarbon dates. We conclude that it is very likely that these sediments were fully reset by daylight exposure prior to burial and that the lower face of the large fragment of the roof was not in contact with the ground. We conclude that the dated sediment corresponds to an interstitial fill accumulated after the Aurignacian occupation and deposition of the GC4 complex (Fig. 5).

\section{Discussion}

\section{Middle Palaeolithic-Châtelperronian-Aurignacian chronostratigraphy}

The ages obtained for Châtelperronian contexts range from $11,910 \pm 200{ }^{14} \mathrm{C}$ yr BP (a charcoal sample from the black unit of the Grotte de Grande Roche at Quincay, Ly-790) to $40,650 \pm 600{ }^{14} \mathrm{C}$ yr
BP (bone sample from the Grotte des Fées at Chatelperron level B5A, OxA-13621), $>40,000{ }^{14} \mathrm{C}$ yr BP (Gif-2414) on a charcoal sample from the level 5B of the Grotte du Loup, and 48,700 \pm 3600 ${ }^{14} \mathrm{C}$ yr BP for a bone sample from level X of the Grotte du Renne at Arcy (Higham et al., 2010). Twenty thermoluminescence ages are available for the Roche à Pierrot at Saint-Césaire. Six burnt flints samples from the Ejop level have produced an average age of $36.3 \pm 2.7 \mathrm{ka}$ (the ages span between $33.7 \pm 5.4 \mathrm{ka}$ and $38.2 \pm 5.3 \mathrm{ka}$, Mercier et al., 1991).

Evin (1970) has suggested that most of the ${ }^{14} \mathrm{C}$ dates beyond $35 \mathrm{ka}$ BP must be considered minimum ages. Conard and Bolus (2003) have interpreted the irregularities of the ${ }^{14} \mathrm{C}$ dates during the $40 \mathrm{ka} \mathrm{BP}-30 \mathrm{ka} \mathrm{BP}$ period as related to fluctuations in radiocarbon production, and suggested that this explains the variability in the dates obtained for the German Aurignacian. They called this the 'Middle Palaeolithic Dating Anomaly', although more recent work has suggested that the variability in the German dates are more likely to be caused by problems in the 

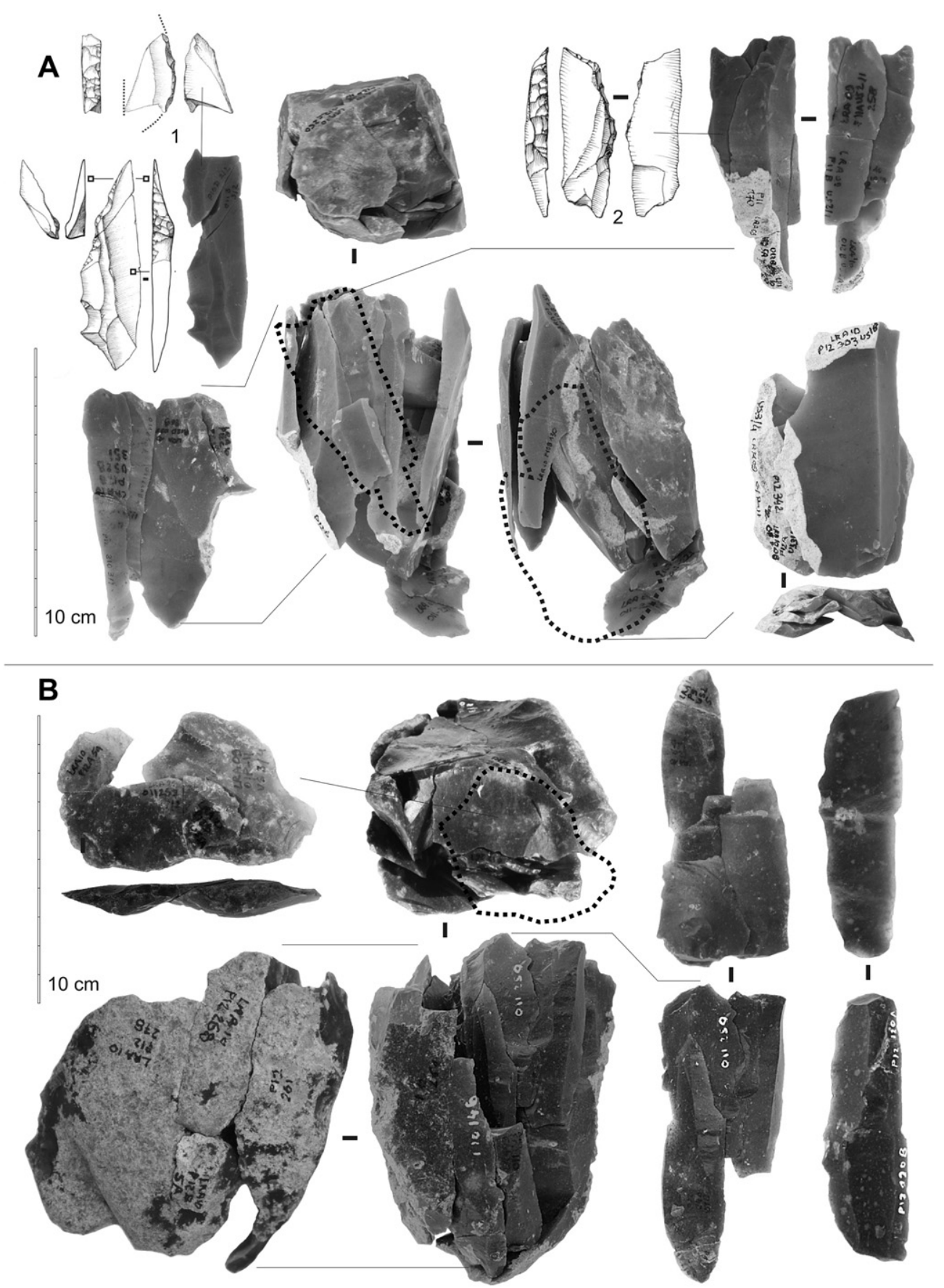

Figure 7. Refits on two prismatic cores corresponding to a Châtelperronian point blades blank reduction sequence from GFU D and the base of GFU E.

removal of contaminants in the samples (Higham, 2011). Similarly, there are no indications of these variations in production rate in the principal calibration datasets obtained since (Reimer et al., 2009). Zilhão and d'Errico (2003) have used the comparison between ages obtained from the same Aurignacian levels of the inner and outside part of the Grotta di Fumane to argue for contamination of bones there by more recent carbon. According to this work, this process must result from percolating groundwater and also affected the bone samples collected in external areas of the Grotte du Renne sequence. Based on this explanation and the hypothesis of a post-depositional mixing with Middle Palaeolithic remains, they refute the oldest dates obtained for the Proto-Aurignacian of Northern Spain and conclude that samples dated from other Châtelperronian sites (Roc de Combe level 8, Grotte des Fées, level B5) are less problematic and indicate that this culture precedes the earliest Aurignacian contexts, which are younger than $36,500{ }^{14} \mathrm{C}$ yr BP (Zilhão and d'Errico, 2003). From a reappraisal and comparison of ${ }^{14} \mathrm{C}$ ages obtained on bone and charcoal, Jorïs et al. (2003) reached a similar conclusion and proposed a slightly younger limit for the oldest Aurignacian contexts in France of $35,400 \pm 708{ }^{14} \mathrm{C}$ yr BP.

Moreover, more recent dating and re-dating by ${ }^{14} \mathrm{C}$ AMS using an ultrafiltration protocol for bone samples recovered in levels assigned to the Châtelperronian (Gravina et al., 2005; Higham et al., 2010), Uluzzian (Higham et al., 2009) and Early Aurignacian (Higham et al., 2006) have systematically revealed results older 

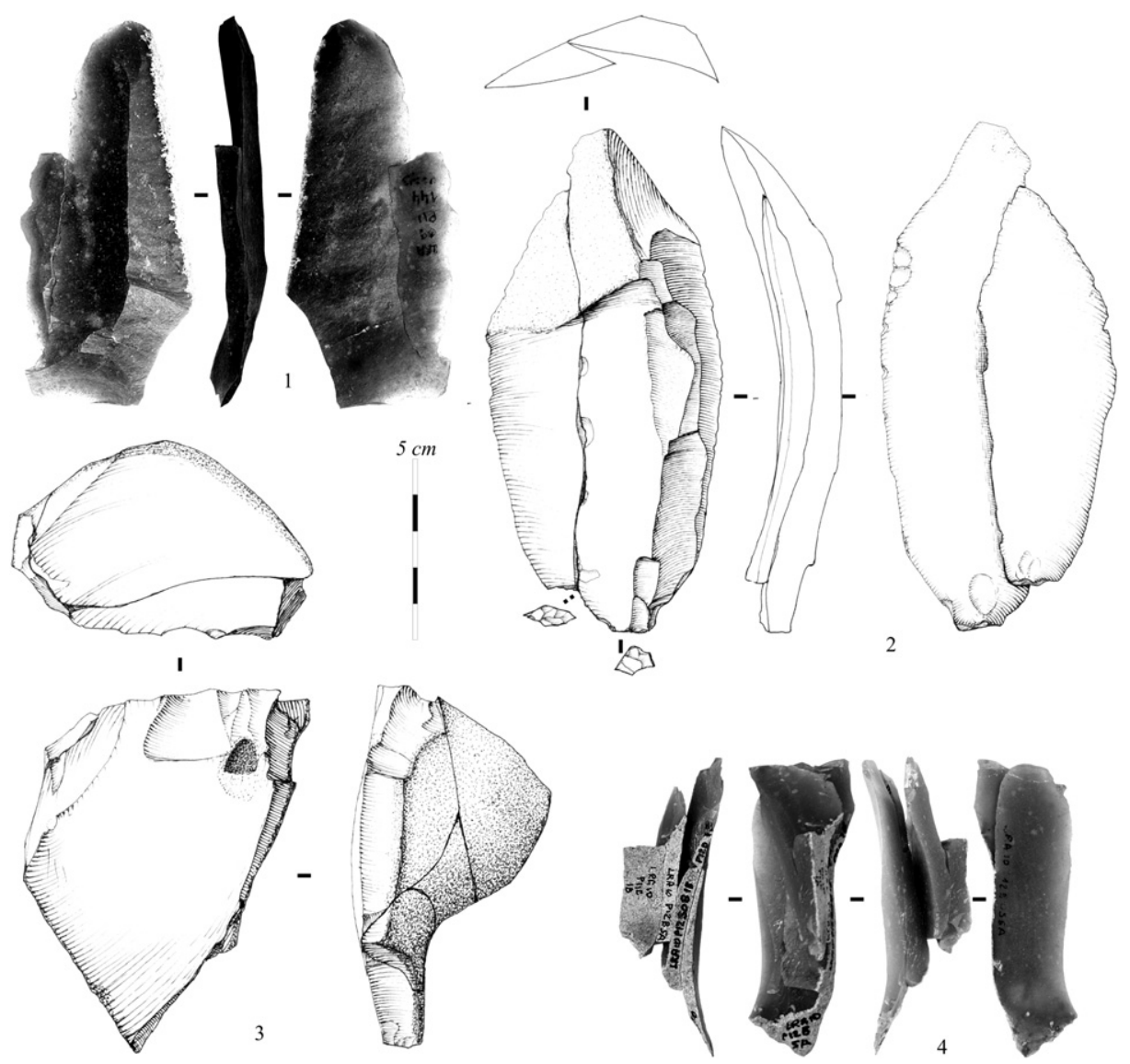

Figure 8. Intercalated large and Châtelperronian blade blank production on prismatic core $(1,2)$, and small blades reduction sequence on large flake core $(3,4)$ found in GFU D and at the bottom of GFU E.

than those obtained when other pre-treatment chemical methods are applied (Higham et al., 2006; Jacobi et al., 2006). The dates obtained for some Aurignacian contexts (Szmidt et al., 2010) appear slightly older, but within the statistical interval, than the maximum age proposed by Zilhão and d'Errico (2003), while also confirming the older age of the Uluzzian transitional technocomplex (Higham et al., 2009). These conclusions have direct implications on the interpretation of the chronology of the Middle to Upper Palaeolithic
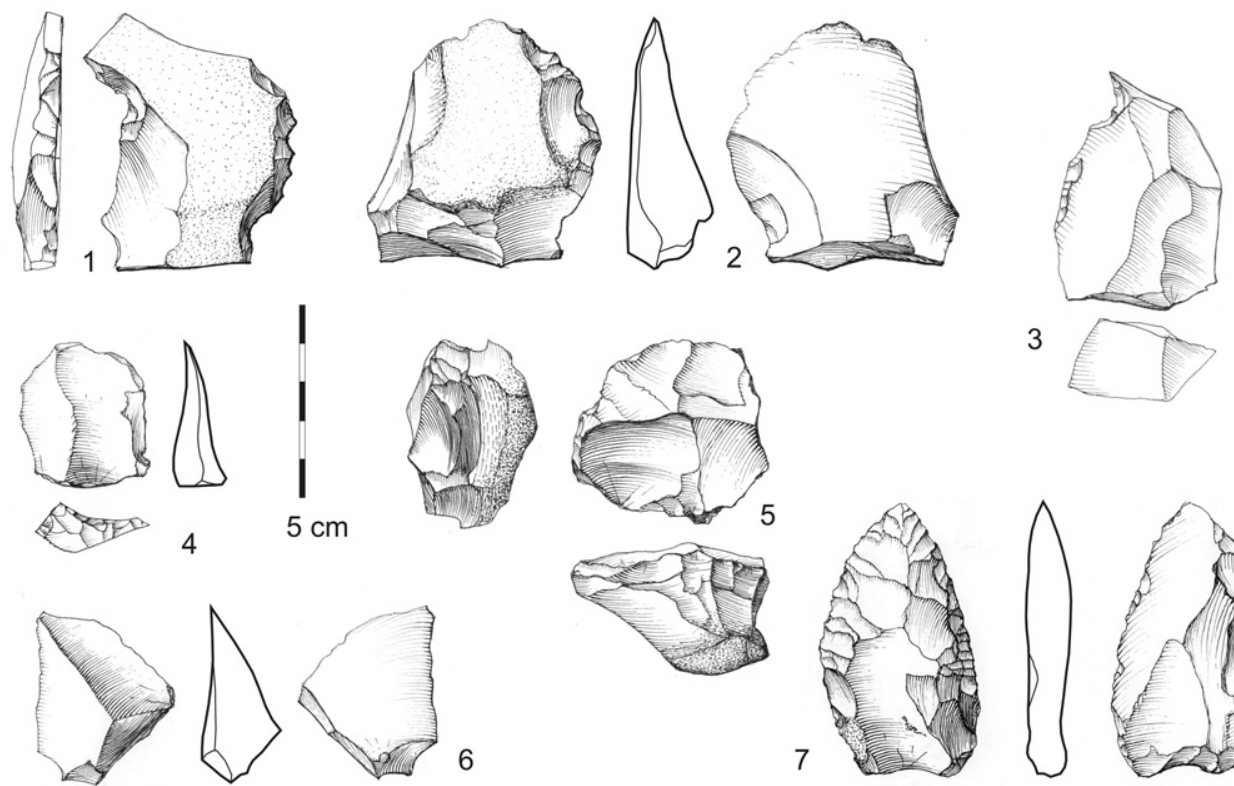

Figure 9. Denticulates $(1,2,3)$, convergent side-scraper (7), discoidal core (5), and flakes produced by a discoidal or centripetal Levallois operative scheme (4, 6) from the GFU D. 

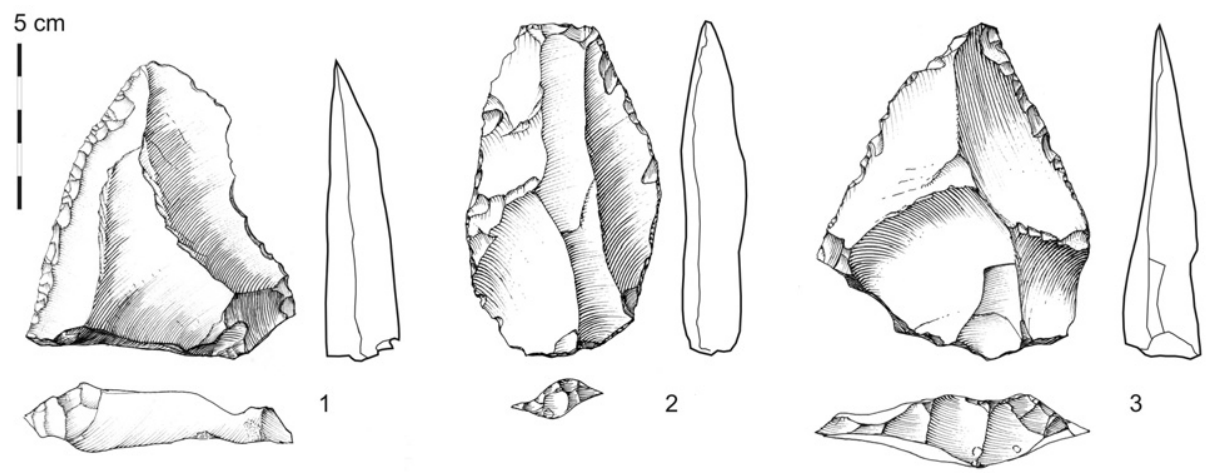

Figure 10. Side-scrapers on large Levallois flake from the GFU A.

sequences, obtained on bones during the last decades by the most commonly applied 'Longin collagen method' (Longin, 1971). Similarly, they relate the significance of the overlap of dates obtained for distinct cultural contexts of bones older than two to three halflives of ${ }^{14} \mathrm{C}$.

The re-dating based on the ultrafiltration protocol of bone samples from the Grotte du Renne sequence, dated previously by the conventional pre-treatment, has confirmed that despite some discrepancy most of the dates associated with Châtelperronian remains are substantially older than the Aurignacian ones (Higham et al., 2010). They span the time interval from $37,500-41,000{ }^{14} \mathrm{C} \mathrm{yr}$ BP, proposed for the Châtelperronian by Zilhão et al. (2006), based on the bone dates for Roc de Combe level 8 and Grotte des Fées level B5.

This proposition seems to be supported by the ${ }^{14} \mathrm{C}$ and OSL results for GFU D of the Bordes-Fitte rockshelter (Tables 2 and 3; Fig. 5). In GFU D, the feldspar age may be slightly older than the quartz age but both are consistent with the radiocarbon ages. If this unit was not completely reset by daylight, the effect on the age is minor. Finally, the heated sample (092201, Table 3), which is more certain to have been fully reset also gives an age in agreement with the immediately overlying ${ }^{14} \mathrm{C}$ age. A fragment of a large bovid long bone from GFU $D$ was pre-treated by collagen extraction with alkali protocol at Beta Analytic (Table 3). The age range of $32,110 \pm 280{ }^{14} \mathrm{C}$ yr BP (37,429-36,230 [90\%] cal yr BP, 35,912-35,606 [5.4\%] cal yr $\mathrm{BP})$ is the only result incoherent with its stratigraphic position (Fig. 5). The size (ca. $15 \mathrm{~cm}$ ), horizontal disposition and the location of the sample dated in an area of the square $\mathrm{O}-10 \mathrm{~B}$, which is not protected by a fragment of the rockshelter roof (Fig. 11A), suggest that the hypothesis of an incomplete decontamination of recent carbon during the pre-treatment is more probable than a downward movement of material derived from the GC5 complex.

The two ${ }^{14} \mathrm{C}$ results reveal that GFU D containing the Châtelperronian lithic remains was deposited between 41,200 \pm 1300 ${ }^{14} \mathrm{C}$ yr BP $(48,010-42,956$ cal yr BP $)$ and $37,400 \pm 800{ }^{14} \mathrm{C}$ yr BP $(43,475-41,045$ cal yr BP). The sediments of GFU D are dated by OSL to $45 \pm 2 \mathrm{ka}$ on the feldspar fraction and to $39 \pm 2 \mathrm{ka}$ on the quartz fraction. The sample dated was collected in the square P-10, where refitting has revealed that Châtelperronian lithic remains of this area were probably removed from the $\mathrm{O} / \mathrm{P}-11 / 12$ squares (Fig. 11B). Thus, the OSL age on the quartz fraction (39 $\pm 2 \mathrm{ka}$ ) provides a terminus ante quem to this human occupation. The data indicate that the Châtelperronian occupation occurs before the collapse of the rockshelter roof and the deposition of the GC4 complex containing the Aurignacian remains and dated between $35,770 \pm 380$ ${ }^{14} \mathrm{C}$ yr BP $\left(41,731-40,135 \mathrm{cal}\right.$ yr BP) and $34,520 \pm 850{ }^{14} \mathrm{C}$ yr BP $(41,475-37,511$ cal yr BP). The OSL date $(51 \pm 3 \mathrm{ka})$ on quartz of a burnt calcarenite fragment from the base of GFU D is stratigraphically consistent with these results and provides a terminus post quem for the Châtelperronian. Our results are thus consistent with the chronology proposed for the Châtelperronian (42.5-45 cal ka BP) by Zilhão et al. (2006), and $\left(38-41^{14} \mathrm{C}\right.$ ka BP) accepted as the most likely dating range by Jorïs and Street (2008, their Fig. 8).

\section{Homogeneity and evolution of the Châtelperronian lithic industry}

The existence of a widespread erosion event between the recent Middle Palaeolithic and the Châtelperronian levels has long been observed (Sonneville-Bordes, 1960; 1972; Laville, 1972), and the importance of freeze-thaw degradation and solifluction affecting the deposits has been put forward as an explanation for the mixed characteristics of most of the Châtelperronian series recovered in karstic sites in south-western France (Peyrony, 1934; 1936; Sonneville-Bordes, 1960; Rigaud, 1996; 2001). Post-depositional degradation has also been inferred from the spatial distribution of the Châtelperronian lithic remains of the open-air occupations of Canaule II and Vieux-Coutet, interpreted as a soil surface sorted polygonal pattern related to the cold conditions during the Heinrich event 4 (Bertran et al., 2010).

However, such mixtures are not the rule. Middle Palaeolithic technological components are absent or rarely found in the lithic series of Canaule II (Bachellerie et al., 2008), and other Châtelperronian open-air sites, such as Tambourets (Bricker and Laville, 1977), la Cote (Pelegrin, 1995), Grotte des Cottés (Primault, 2003; Soressi et al., 2010), in Châtelperronian levels Ejf to Ejo of La Grande Roche at Quinçay (Lévêque, 1987; Roussel and Sorressi, 2010), at the Grotte du Loup (Mazière and Tixier, 1976) and in Labeko Koba level IX (Basque Country) (Arrizabalaga and Altuna, 2000). The proportion of discoidal components in the total core assemblage is comprised at between 6\% (level X) and 2\% (level VIII) at the Grotte du Renne (Connet, 2002). In a recent technological reappraisal of the Roche à Pierrot at Saint-Césaire, Ejop inf is assigned to the Middle Palaeolithic and Ejop sup to the Châtelperronian (Soressi, 2010). The Ejop sup level appears to comprise a duality in its technological forms, with almost $50 \%$ of the lithics being scrapers and more than $50 \%$ cores that exclusively produced flakes. This is mirrored amongst the lithic assemblages of levels X-VIII at Arcysur-Cure (Farizy, 1990; Gouedo, 1990; Connet, 2002). This association has been interpreted as representative of an early evolutionary phase of the Châtelperronian (Lévêque, 1987; Farizy, 1990).

Nevertheless, the homogeneity of the Saint-Césaire Ejop sup lithic assemblage has been questioned by some authors (Bordes, 1981; Sonneville-Bordes, 1989; Rigaud, 1996; Bar-Yosef, 2006). A spatial study of the lithics and faunal remains in the Ejop sup level at Saint-Césaire has revealed, on the one hand, a clear association 

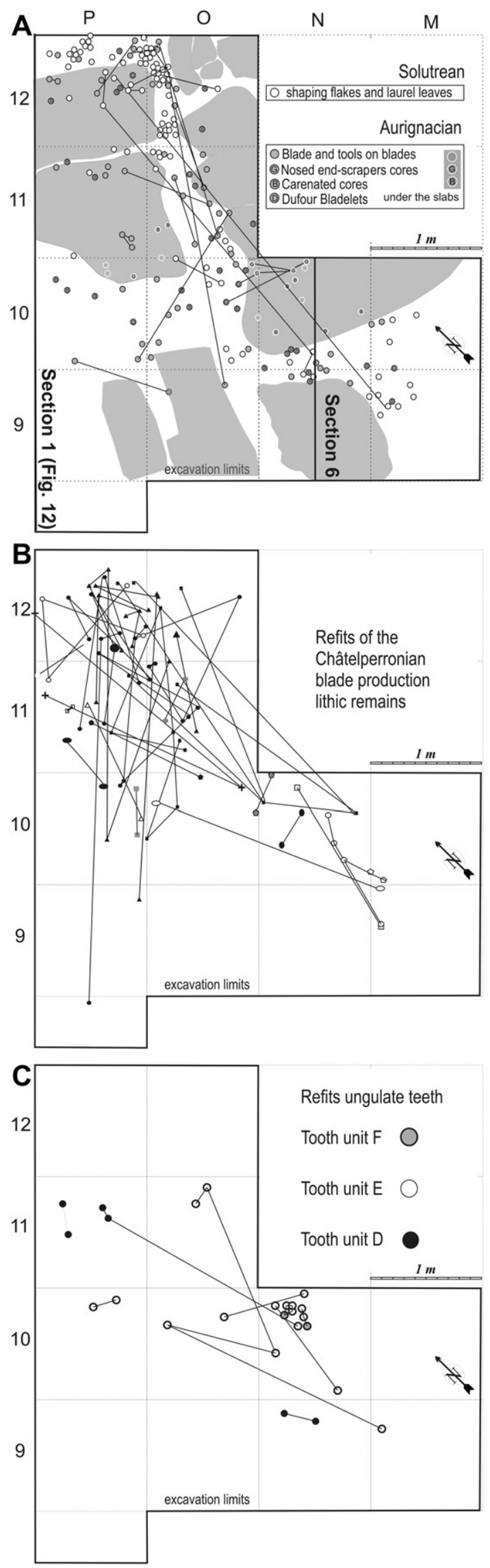

between bovid remains and technologically Middle Palaeolithic lithics and, on the other hand, between Reindeer remains and Châtelperronian points (Backer, 1993). Furthermore, significant similarities have been noted in lithic reduction strategies between the 'Mousterian' component in the Ejop level and the Denticulate Mousterian of Egpf (Guilbaud et al., 1994).

In an attempt to clarify the doubts concerning the integrity of the sequence and the homogeneity of the Ejop sup level, which has a central role in the theory of a Neanderthal association with the Châtelperronian, systematic bone refits of eight stratigraphical faunal assemblages of the Roche à Pierrot at Saint-Césaire sequence were carried out by Morin et al. (2005). This study confirmed that the horse and bison/reindeer proportion varies according to the distance from the cliff not only in level Ejop sup but also in other levels. The rarity of inter-layer refits has been put forward as an argument against the contamination of Ejop sup by material from the Middle Palaeolithic lower levels and to confirm the homogeneity of the lithic assemblages recovered in the sequence (Hublin and Bailey, 2006).

The hypothesis of the accumulation of Denticulate Middle Palaeolithic and Châtelperronian materials in the same sedimentary unit, as proposed by Guilbaud et al. (1994), has been also rejected given the difference between the average $\mathrm{TL}$ age of $36.3 \pm 1.3 \mathrm{ka}$ obtained for the Ejop sup level and $40.28 \pm 1.84 \mathrm{ka}$ obtained for level Egpf and considering "that the earliest Châtelperronian occupations in France and Spain are dated around 38 ka and 39 ka" (Morin et al., 2005).

Considering the discrepancy between the TL ages of the Roche à Pierrot at Saint-Césaire Ejop sup level (Mercier et al., 1991) and the results obtained by radiocarbon AMS using an ultrafiltration protocol of bone samples recovered in levels assigned to the Châtelperronian (Gravina et al., 2005; Zilhão et al., 2006; Higham et al., 2010), one can ask if the chronological argument advanced by Morin et al. (2005) is still valid and if the mixed character attested in the Ejop sup level is the result of successive activities separated by a long interval of time or the consequence of a new transition technology, characteristic of the Châtelperronian culture.

The data obtained from the typo-technological and spatial studies of the Bordes-Fitte GFU D show that the Middle and Upper Palaeolithic components are made from different raw materials, have different technological characteristics, spatial distribution and refit ratios. These four facts could be explained as the result of different functions, places of production and differences between tools made on flake and on blades. The flake tools could have been produced near to local sources, or other extra-regional Lower Turonian flint sources, or in other locations around the Roches d'Abilly site, whereas the Châtelperronian blanks and points produced from local flint, would have been made at the site. Against this explanation, the vertical distribution of the two technological components (Fig. 12) indicates a distinct spatial distribution and post-depositional displacement pattern, probably resulting from the existence of two successive phases of occupation and distinct post-depositional movements. The most parsimonious explanation is the existence of a sedimentary hiatus between the Denticulate Mousterian occupation, represented by the discoidal and Levallois method, bearing burnt pieces and spatially associated with burnt silicified limestone detected at the limit between the GC2 and GC3 complexes (Fig.4). The existence of a hiatus is suggested by the time interval between the age of $51 \pm 3 \mathrm{ka}$, obtained for the burnt calcarenite fragment recovered at the base of the GFU

Figure 11. Horizontal plot of lithic remains assigned to the Solutrean (A), Aurignacian (B), Châtelperronian (C) and tooth refits from a total of 518 analyzed (ungulates: 463, carnivores: 55) (C). 

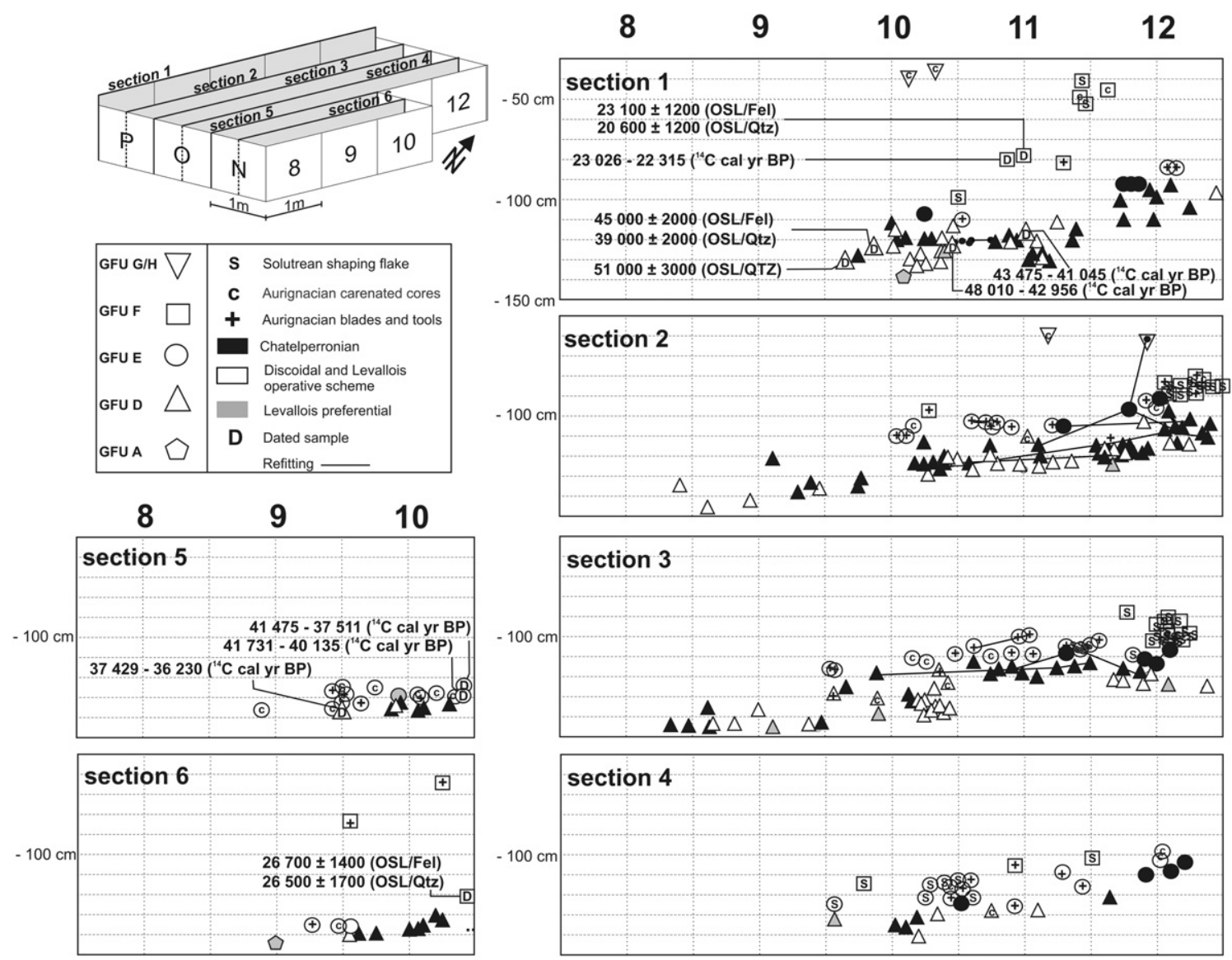

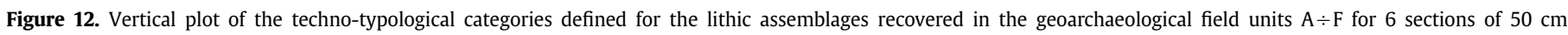
(see Fig. 11).

$\mathrm{D}$, the complete absence of burnt pieces in the blade production component of GFU D, and the ages of $39 \pm 2 \mathrm{ka}$ and $45 \pm 2 \mathrm{ka}$ obtained for the GFU D sediment. Denticulate Mousterian occupation would thus have taken place around $51 \mathrm{ka}$ (as observed in the French south-eastern Middle Paleolithic occupation sequences; Vieillevignes et al., 2008), well before the Châtelperronian.

Although a superficial analysis of the lithic assemblage preservation stage could have suggested that the Châtelperronian material corresponds to an original mix of Middle and Upper Palaeolithic technologies, the careful taphonomic study of the Bordes-Fitte rockshelter GFU D shows otherwise; the mix is of two occupation phase remains, not two coeval technologies. The best analogies for the most recent blade component are found in the open-air sites of les Tambourets (Bricker and Laville, 1977), Canaule (Bachellerie et al., 2008), La Côte (Pelegrin, 1995), Roc de Combe (Pelegrin, 1995) and in the Châtelperronian levels of la Grande Roche at Quinçay (Roussel and Sorressi, 2010).

The existence of several evolutionary phases in the Châtelperronian lithic technologies was originally proposed by Lévêque (1987). The oldest, named Proto-Châtelperronian, is characterized by numerous side-scrapers, denticulates and a few bifaces associated with burins, end-scrapers on blades and backed pieces. The series from level B at the Grotte XVI was assigned to this first phase (Lucas et al., 2003). However, the first results of a technological study of the Grande Roche at Quinçay sequence (Roussel and Sorressi, 2010) show that the lithic production associated with level Egc must be assigned, in fact, to the Mousterian of Acheulean Tradition and that levels Egf to Ejo both yielding homogenous Châtelperronian blade blanks for backed point production throughout are technologically the same.
The hypothesis of the existence of evolution from the Middle Palaeolithic reduction sequences to the Châtelperronian point production (Soressi, 2010) cannot be definitively discarded yet. However, the putative transitional technological stages remain to be found and the evidence from Quinçay (Roussel and Sorressi, 2010) reveals distinct blank production sequences, retouch techniques, and morphologies for the backed tools of the Mousterian of Acheulean Tradition (MTA) and the Châtelperronian (Roussel and Sorressi, 2010). The characteristic bifacial technology of the MTA (Soressi, 2002) is completely absent in the open-air Châtelperronian sites. The superposition of MTA B and Châtelperronian site distribution patterns has been used to argue for continuity between the two (Pelegrin and Soressi, 2007). However, a similar distribution pattern can be observed well after the MTA, for lithic tools types and artistic conventions during the Upper Palaeolithic, suggesting that environmental forcing could be an alternative explanation and the current evidence is that, in stratified sequences, the latest Middle Palaeolithic is a Denticulate Mousterian (Vieillevignes et al., 2008; Bar-Yosef and Bordes, 2010).

\section{Who were the makers of the Châtelperronian technology?}

The issue of 'who made these tools' is crucial in the debate regarding the transition from the Middle to the Upper Palaeolithic (Gambier et al., 2004; Zilhão et al., 2006; Bar-Yosef, 2006; Bailey et al., 2009; Bar-Yosef and Bordes, 2010; Green et al., 2010).

The Combe-Capelle burial is now known to be Mesolithic (Hoffmann et al., 2011) and all diagnostic human remains found in late Middle Palaeolithic contexts are Neanderthal. As for the 'transitional' assemblages, the Châtelperronian is the only one that 

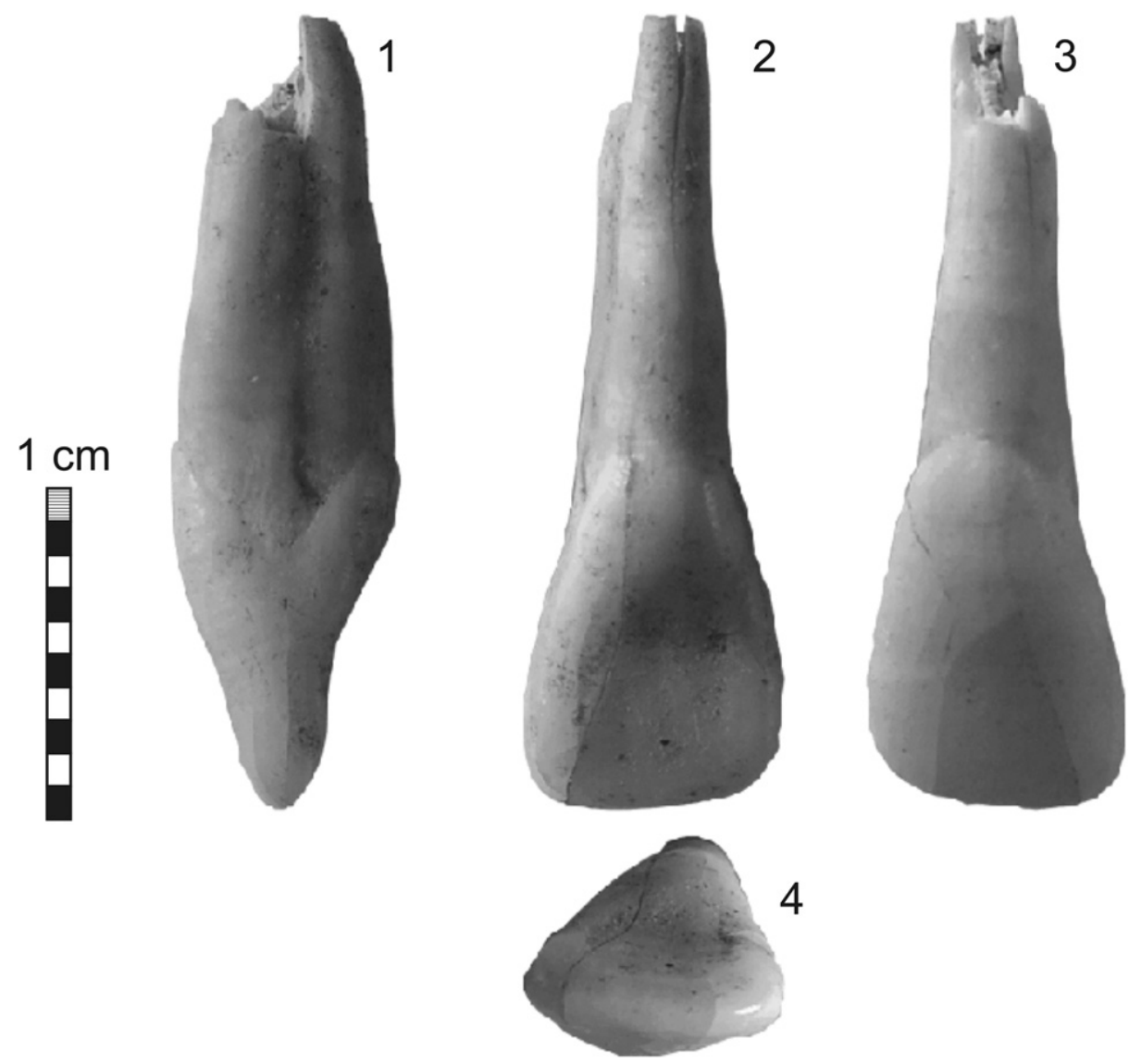

4

Figure 13. The Roches d'Abilly Bordes-Fitte rockshelter \#1, right maxillary incisor (N-9 \#18), (1) distal face, (2) lingual face, (3) labial face, (4) incisal edge.

has yielded significant human remains from two sites, both clearly Neanderthal (Lévêque and Vandermeersch, 1980; Hublin et al., 1996; Bailey and Hublin, 2006). However, the morphological characteristics of isolated human remains are often nondiscriminant, most dental features are shared (Gambier et al., 2004), and the number of human remains available for the time spanning between $30 \mathrm{ka}$ and $40 \mathrm{ka}$ is very limited.

The homogeneity of the assemblages and the association of the Neanderthal human remains with the Châtelperronian blade production must be re-evaluated, considering the singular technological composition of the Ejop sup lithic assemblage of the Roche à Pierrot at Saint-Césaire. At the Grotte du Renne, the association of the diagnostically Châtelperronian lithics with diagnostically Neanderthal human remains has been explained by an admixture of Middle Palaeolithic elements within the Châtelperronian levels as the result of digging and leveling during the first Châtelperronian occupation of the site or by post-depositional processes (Movius, 1969; White, 2001; Bordes, 2006a; Bar-Yosef and Bordes, 2010). The wide-ranging ${ }^{14} \mathrm{C}$ AMS results obtained on bones from the Châtelperronian levels X-VIII of the Arcy-surCure's sequence, spanning from $21,150 \pm 160{ }^{14} \mathrm{C}$ yr BP to $48,700 \pm 3600{ }^{14} \mathrm{C}$ yr BP, have been interpreted as an argument that material from several contexts has moved both up and down the stratigraphic sequence into the Châtelperronian levels (Higham et al., 2010). The result of $48,700 \pm 3600{ }^{14} \mathrm{C} \mathrm{yr}$ BP from level $\mathrm{X}$ is interpreted as the dating of a bone sample derived from the lower Mousterian levels. The awl dated to $37,000 \pm 1000{ }^{14} \mathrm{C}$ yr BP, and rib fragment with cut marks to $38,200 \pm 1200{ }^{14} \mathrm{C}$ yr BP, located in the Middle Palaeolithic level XII, but recovered in an area in which there had been extensive disturbance, are interpreted as derived from the Châtelperronian occupation. Thus, the dates obtained suggest a post-depositional disturbance that has to be evaluated in terms of process and extent; they do not reveal clearly that Middle Palaeolithic material moved up during the Châtelperronian occupation.

In this context, the maxillary incisor discovered in the square N9 of the Bordes-Fitte rockshelter at the top of GFU D (yielding Châtelperronian and Middle Palaeolithic lithic components) directly under the GC4 complex (Aurignacian lithic and faunal remains mixed with a patinated Middle Palaeolithic lithic component) is of major interest. However, its location adjacent to a collapsed roof fragment and at the erosional limit between GC3 and GC4 complexes, does not permit secure archaeological assignment to one of these different occupations.

This isolated specimen is a permanent right $\mathrm{I}^{2}$ (Fig. 13). The crown is completely formed but the root apex is still open, suggesting a developmental age less than nine to 11 years (Smith, 1991; Hillson, 2003). The specimen is very fragile, presenting longitudinal cracks in both the crown and the root. The labial surface is also marked by a series of fine scratches in a diverse range of orientations. On the lingual surface, the enamel is covered with a thin layer of sediment. The apical portion of the root is in a particularly delicate condition, with the tip broken away. An occlusal attrition facet extending along the incisal edge was recorded (Smith, 1984; stage 2).

In all, metric (especially buccal-lingual diameter $=6.8 \mathrm{~mm}$ ) and non-metric data (according to ASUDAS system) strongly suggest that this tooth did not belong to a Neanderthal specimen. Also nonmetrical diagnostic features typical in Neanderthals are absent (namely, tuberculum dentale), shovel shape or double shovel shape traits (all ASUDAS $=0$ ). 


\section{Conclusions}

Archaeological research carried out since 2007 at the Roches d'Abilly site has revealed a sequence of human occupations that sheds new light on the Middle to Upper Palaeolithic transition. The total $3 \mathrm{~m}$-thick deposit preserved at the Bordes-Fitte rockshelter is composed of typical near-surface (shallow) sedimentary facies, where autochthonous and allochthonous inputs easily mingle, in a context dominated by run-off and gravitational sedimentary processes. The stratigraphic sequence results from several episodes of sediment slope-wash and endokarst dynamics, with several hiatuses and important erosional phases. While the stratigraphic record reveals a complex taphonomic history and alteration of the original spatial organization of the archaeological remains, as attested in most of the rockshelter and cave entrance sequences where a geaoarchaeological approach was applied (Goldberg and Macphail, 2006; Texier, 2009), the human input, sedimentary sources and dynamics could be defined, and the processes and amplitude of the degradation evaluated.

Few sites contain inter-stratified Châtelperronian lithic industries, and most were excavated in an early phase or are still only partially published. The archaeological work and study carried out between 2007 and 2010 at the Abri Bordes-Fitte rockshelter allow us to establish that the lithic assemblage from the GFU D, comprising the Châtelperronian blade and Middle Palaeolithic flake production, is not homogeneous and corresponds to an accumulation of remains discarded during successive occupations preserved within a single stratigraphic unit. Châtelperronian point remains present a high refit ratio that permits a precise reconstruction of various reduction sequences, and the refit set spatial distribution indicates a low degree of post-depositional degradation. This result has important implications for the interpretation of knapping activities and this site's function, as well as other inter-stratified Châtelperronian lithic assemblages purporting to display transitional technological characteristics and to define its affinities to earlier and later industries.

Our data offer new evidence on the timing and chronostratigraphical relationship of the Middle Palaeolithic, Châtelperronian and Aurignacian occupations in a region intermediary between the Paris Basin and southern France. Denticulate Mousterian, the youngest Middle Palaeolithic occupation of the rockshelter, is dated around $51 \mathrm{ka}$. The ages obtained by ${ }^{14} \mathrm{C}$ AMS and OSL on samples from the GFU D, and the evaluation of postdepositional degradation permit us to place the Châtelperronian occupation in the $41 \mathrm{ka}-48 \mathrm{ka}$ interval. This Châtelperronian occupation predates an episode of rockshelter collapse followed by a main erosional event, and the deposition of the GC4 complex dated to around $41{ }^{14} \mathrm{C}$ cal ka BP that contains Aurignacian remains in secondary position.

The maxillary incisor recovered at the top of GFU D (bearing most of the Châtelperronian component but immediately overlain by Aurignacian-bearing GC4 complex) should be better characterized by high-resolution microtomography. Also, direct ${ }^{14} \mathrm{C}$ AMS dating as well as the continuation of the field work at the BordesFitte rockshelter and other Middle and Early Upper Palaeolithic occupations detected along the Roches d'Abilly cliff site, will clarify the relation between this fossil and the different human occupations recorded in adjacent levels.

\section{Acknowledgments}

Field work and analyses were supported by the Service Régional de l'Archéologie de la Région Centre (French Ministry of Culture). We thank the Smith family, owners of the Roches d'Abilly site, who kindly authorized the archaeological field work and Pedro Proença Cunha (IMAR - Marine and Environmental Research Centre,
University of Coimbra, Portugal) for the preparation of the OSL samples. We would like to thank J. Zilhão (University of Barcelona, Faculty of Geography and History, Department of Prehistory, Ancient History, and Archaeology) for stimulating discussions and helpful remarks. Constructive comments on an earlier version of the manuscripts by J. Dinis (Dep. of Earth Sciences, University of Coimbra, Portugal) were gratefully acknowledged. Finally, we would also like to thank the anonymous reviewers for their stimulating and useful suggestions on a first draft of this paper.

\section{References}

Aitken, M.J., 1985. Thermoluminescence Dating. Academic Press, London.

Aitken, M.J., 1998. An Introduction to Optical Dating. Oxford University Press, Oxford.

Allain, J., 1976. Les civilisations du Paléolithique supérieur dans le sud-ouest du bassin parisien. In: de Lumley, H. (Ed.), La Préhistoire Française. Editions CNRS, Paris, pp. 1315-1320.

Angelucci, D.E., 2002. The geoarchaeological context. In: Zilhão, J., Trinkaus, E. (Eds.), Portrait of the Artist as a Child. The Gravettian Human Skeleton from the Abrigo Do Lagar Velho and Its Archaeological Context, vol. 22. Trabalhos de Arqueologia, pp. 58-91.

Arrizabalaga, A., Altuna, J., 2000. Labeko Koba (País Vasco). Hienas y Humanos en los albores del Paleolítico superior. Munibe 52, 395.

Aubry, T., 1991. L'exploitation des ressources en matières premières lithiques dans les gisements solutréens et badegouliens du bassin versant de la Creuse (France), Ph.D. Dissertation, University of Bordeaux I.

Aubry, T., Almeida, M., Chehmana, L., Thiennet, H., Walter, B., 2007. De la fin du Solutréen au Magdalénien moyen dans les vallées de la Claise et de la Creuse. Bull. Soc. Préhist. Fr. 104, 699-714.

Aubry, T., Dimuccio, L.A., Almeida, M., Neves, M.J., Angelucci, D.E., Cunha, L., 2010. Palaeoenvironmental forcing during the middle-upper palaeolithic transition in central-western Portugal. Quatern. Res. doi:10.1016/j.yqres.2010.11.002.

Bachellerie, F., Bordes, J.G., Morala, A., Pelegrin, J., 2008. Étude typo-technologique et spatiale de remontages lithiques de Canaule II, site Châtelperronien de pleinair en Bergeracois. Paléo 19, 259-280.

Backer, A.M., 1993. Spatial distribution at la Roche à Pierrot, Saint-Césaire: changing uses of a rockshelter. In: Lévêque, F., Backer, A.M., Guilbaud, M. (Eds.), Context of a Late Neandertal: Implication of Multidisciplinary Research for the Transition to Upper Paleolithic Adaptation. Prehistory Press, Madison, pp. 105-127.

Bailey, S.E., Hublin, J.-J., 2006. Dental remains from Grotte du Renne at Arcy-surCure (Yonne). J. Hum. Evol. 50, 485-508.

Bailey, S.E., Weaver, T.D., Hublin, J.-J., 2009. Who made the Aurignacian and other early Upper Paleolithic industries? J. Hum. Evol. 57, 11-26.

Bar-Yosef, O., 2006. Defining the Aurignacian. Trabalhos de Arqueologia 45, 11-18.

Bar-Yosef, O., Bordes, J.G., 2010. Who were the makers of the Châtelperronian culture? J. Hum. Evol. 59, 586-593.

Bertran, P., Klaric, L., Lenoble, A., Masson, B., Vallin, L., 2010. The impact of periglacial processes on Palaeolithic sites: the case of sorted patterned grounds. Quatern. Int. 214, 17-29.

Bodu, P., 1990. L'application de la méthode des remontages à l'étude du matériel des premiers niveaux châtelperroniens de la Grotte du Renne à Arcy-sur-Cure. In: Farizy, C. (Ed.), Paléolithique moyen récent et Paléolithique supérieur ancien en Europe. Colloque international de Nemours. APRAIF, Nemours, pp. 309-312. 9-11 mai 1989.

Boëda, E., 1993. Le débitage Discoïde et le débitage Levallois récurrent centripète. Bull. Soc. Préhist. Fr. 90, 392-404.

Bon, F., 2002. L'Aurignacien entre Mer et Océan. Réflexion sur l'unité des phases anciennes de l'Aurignacien dans le sud de la France. Mém. Soc. Préhist. Fr. 29. Société Préhistorique Française, Paris.

Bordes, F., 1958. Le passage du Paléolithique moyen au Paléolithique supérieur. In: Von Koenigswald, G.H.R. (Ed.), Neanderthal Centenary, 1856-1956, Kemink en Zoon. Utrecht, pp. 175-181.

Bordes, F., 1968. La question périgordienne. In: La préhistoire: problèmes et tendances. CNRS, Paris, pp. 59-70.

Bordes, F., 1981. Un Néandertalien encombrant. La Recherche 122, 644-645.

Bordes, F., Fitte, P., 1950. Un abri solutréen à Abilly (Indre et Loire). Bull. Soc. Préhist. Fr. 47, 146-153.

Bordes, F., Labrot, J., 1967. La stratigraphie du gisement de Roc de Combe et ses implications. Bull. Soc. Préhist. Fr. 64, 15-28.

Bordes, J.G., 2003. Lithic taphonomy of the Châtelperronian/Aurignacian interstratifications in Roc de Combe and Le Piage (Lot, France). Trabalhos de Arqueologia 33, 223-244.

Bordes, J.G., 2006a. Le premier européen moderne. La Recherche 24, 79-83.

Bordes, J.G., 2006b. News from the West: a reevaluation of the classical Aurignacian sequence of the Périgord. Trabalhos de Arqueologia 45, 147-171.

Bricker, H.-M., Laville, H., 1977. Le gisement Châtelperronien de plein air des Tambourets (Commune de Couladère, Haute-Garonne). Bull. Soc. Préhist. Fr. 74, 505-517. 
Brock, F., Higham, T.F.G., Ditchfield, P., Bronk Ramsey, C., 2010a. Current pretreatment methods for AMS radiocarbon dating at the Oxford radiocarbon accelerator unit (ORAU). Radiocarbon 52, 103-112.

Brock, F., Higham, T., Bronk Ramsey, C., 2010b. Pre-screening techniques for identification of samples suitable for radiocarbon dating of poorly preserved bones. J. Archaeol. Sci. 37, 855-865.

Bronk Ramsey, C., 2009. Dealing with outliers and offsets in radiocarbon dating. Radiocarbon 51, 1023-1045.

Bronk Ramsey, C., Buck, C.E., Manning, S.W., Reimer, P., van der Plicht, H., 2006 Developments in radiocarbon calibration for archaeology. Antiquity 80, 783-798.

Bronk Ramsey, C., Higham, T.F.G., Bowles, A., Hedges, R., 2004. Improvements to the pre-treatment of bone at Oxford. Radiocarbon 46, 155-163.

Bullock, P.N., Fedoroff, N., Jongerius, G.J., Stoops, G., Tursina, T., Babel, U. (Eds.), 1985. Handbook for Soil Thin Section Description. Waine Research Publishers, Wolverhampton.

Buylaert, J.P., Jain, M., Murray, A.S., Thomsen, K.J., Thiel, C., Sohbati, R.A. Robust method for increasing the age range of feldspar IRSL dating. Boreas, submitted for publication.

Buylaert, J.P., Murray, A.S., Thomsen, K.J., Jain, M., 2009. Testing the potential of an elevated temperature IRSL signal from K-feldspar. Radiat. Meas. 44, 560-565.

Campy, M., Bintz, P., Evin, J., Laville, H., Chaline, J., 1994. Sedimentary record in French karstic infillings during the last climatic cycle. Quaternaire 5, 157-163.

Champagne, F., Espitalié, R., 1967. La stratigraphie du Piage. Note préliminaire. Bull. Soc. Préhist. Fr. 64, 29-34.

Conard, N.J., Bolus, M., 2003. Radiocarbon dating the appearance of modern humans and timing of cultural innovations in Europe: new results and new challenges. J. Hum. Evol. 44, 331-371.

Connet, N., 2002. Le Châtelperronien: Réflexion sur l'unité et l'identité technoéconomique de l'industrie lithique: L'apport d'analyse Diachronique des Industries lithiques des couches châtelperroniennes de la Grotte du renne à Arcy-sur-Cure (Yonne). Ph.D. Dissertation, University of Lille 1.

Courty, M.A., Goldberg, P., Macphail, R., 1989. Soils and Micromorphology in Archaeology. Cambridge University Press, Cambridge.

d'Errico, F., 2003. The Invisible Frontier. A multiple species model for the origin of behavioral modernity. Evol. Anthropol. 12, 188-202.

Demars, P.Y., Hublin, J.-J., 1989. La transition néanderthaliens/hommes de type moderne en Europe occidentale: aspect paléontologiques et culturels. In: Otte, M. (Ed.), L'Homme de Néanderthal, vol. 7. University of Liège, Liège, pp. 23-37.

Dercourt, J., 2002. Géologie et Géodynamique de la France. Outre-mer et européenne. Dunod, Paris.

Djindjian, F., Koslowski, J., Bazile, F., 2003. Europe during the early Upper Paleolithic (40 000-30 000 BP): a synthesis. Trabalhos de Arqueologia 33, 29-47.

Evin, J., 1970. Validity of the radiocarbon dates beyond 35,000 years B.P. Palaeogeogr. Palaeoclimatol. Palaeoecol. 80, 71-78.

FAO-Isric, 1990. Guidelines for Soil Description, third ed. FAO, Roma.

Farizy, C., 1990. Du Moustérien au Châtelperronien à Arcy-sur-Cure: un état de la question. In: Farizy, C. (Ed.), Paléolithique moyen récent et Paléolithique supérieur ancien en Europe. Colloque international de Nemours. APRAIF, Nemours, pp. 281-289. 9-11 Mai 1989.

Fernandes, P., Raynal, J.P., Moncel, M.H., 2008. Middle Palaeolithic raw material gathering territories and human mobility in the southern Massif Central, France: first results from a petro-archaeological study on flint. J. Archaeol. Sci. 35, 2367-2370.

Fontana, L., Digan, M., Aubry, T., Mangado Llach, J., Chauvière, F.-X., 2009. Appréhender les territoires des sociétés du Paléolithique supérieur à partir de l'étude de l'exploitation de leurs ressources: L'exemple du Massif central français. In: Djindjian, F., Kozlowski, J., Bicho, N. (Eds.), Proceedings of the XV World Congress UISPP (Lisbon, 4-9 September 2006) - Le concept de territoires dans le Paléolithique supérieur européen, BAR S1938 2009, pp. 201-215.

Gambier, D., Maureille, B., White, R., 2004. Vestiges humains des niveaux de l'Aurignacien ancien du site de Brassempouy (Landes). Bull. Soc. Anthropol. 16, 49-87.

Godfrey-Smith, D.L., Huntley, D.J., Chen, W.H., 1988. Optically dating studies of quartz and feldspar sediment extracts. Quatern. Sci. Rev. 7, 373-380.

Goldberg, P., Macphail, R.I., 2006. Practical and Theoretical Geoarchaeology. Blackwell Publishing, London.

Gouedo, JJ. 1990. Les technologies lithiques du Châtelperronien de la couche X de la Grotte du Renne d'Arcy-sur-Cure (Yonne). In: Farizy, C. (Ed.), Paléolithique moyen récent et Paléolithique supérieur ancien en Europe. Colloque international de Nemours. APRAIF, Nemours, pp. 305-308.

Gravina, B., Mellars, P., Bronk Ramsey, C., 2005. Radiocarbon dating of interstratified Neanderthal and early modern human occupations at the Châtelperronian type-site. Nature 438, 51-56.

Green, R.E., Krause, J., Briggs, A.W., Maricic, T., Stenzel, U., Kircher, M., Patterson, N., Li, H., Zhai, W., Fritz, M.H.Y., Hansen, N.F., Durand, E.Y., Malaspinas, A.-S., Jensen, J.D., Marques-Bonet, T., Alkan, C., Prüfer, K., Meyer, M., Burbano, H.A., Good, J.M., Schultz, R., Aximu-Petri, A., Butthof, A., Höber, B., Höffner, B. Siegemund, M., Weihmann, A., Nusbaum, C., Lander, E.S., Russ, C., Novod, N., Affourtit, J., Egholm, M., Verna, C., Rudan, P., Brajkovic, D., Kucan, Z., Gušic, Y., Doronichev, V.B., Golovanova, L.V., Lalueza-Fox, C., de la Rasilla, M., Fortea, J., Rosas, A., Schmitz, R.W., Johnson, P.L.F., Eichler, E., Falush, D., Birney, E. Mullikin, J.C., Slatkin, M., Nielsen, R., Kelso, J., Lachmann, M., Reich, D., Pääbo, S., 2010. A draft sequence of the Neandertal genome. Science 328, 710-722.
Guilbaud, M., Backer, A.M., Lévêque, F., 1994. Technological differentiation associated with the Saint-Césaire Neandertal. Préhistoire Européenne 6, 187-196.

Guilbaud, M., 1993. Debitage from the Upper Castelperronian level at Saint-Césaire: methodological approach and implications for the transition from the middle to Upper Paleolithic. In: Lévêque, F., Backer, A.M., Guilbaud, M. (Eds.), Context of a Late Neandertal: Implication of Multidisciplinary Research for the Transition to Upper Paleolithic Adaptation at Saint-Césaire. Prehistory Press, Madison, pp. 37-58.

Guillocheau, F., Robin, C., Allemand, P., Bourquin, S., Brault, N., Dromart, G., Friedenberg, R., Garcia, J.-P., Gaulier, J.-M., Gaument, F., Grosdoy, B., Hanot, F., Le Strat, P., Mettraux, M., Nalpas, T., Prijac, C., Rigollet, C., Serrano, O., Grandjen, G., 2000. Meso-Cenozoic geodynamic evolution of the Paris Basin: 3D stratigraphic constraints. Geodinamica Acta 13, 189-246.

Harrold, F.-B., 1989. Mousterian, Châtelperronian and early Aurignacian inWestern Europe: continuity or discontinuity? In: Mellars, P., Stringer, C. (Eds.), The Human Revolution: Behavioural and Biological Perspectives on the Origin of Modern Humans. Princeton University Press, Princeton, pp. 677-713.

Higham, T., Jacobi, R., Julien, M., David, F., Basell, L., Wood, R., Davies, W., Bronk Ramsey, C., 2010. Chronology of the Grotte du Renne (France) and implications for the context of ornaments and human remains within the Châtelperronian. Proc. Natl. Acad. Sci. doi:10.1073/pnas.1007963107.

Higham, T.F.G., 2011. European Middle and Upper Palaeolithic radiocarbon dates are often older than they look: problems with previous dates and some remedies. Antiquity 85, 235-249.

Higham, T.F.G., Brock, F., Peresani, M., Broglio, A., Wood, R., Douka, K., 2009. Problems with radiocarbon dating the middle to upper Palaeolithic transition in Italy. Quatern. Sci. Rev. 28, 1257-1267.

Higham, T.F.G., Jacobi, R.M., Bronk Ramsey, C., 2006. AMS Radiocarbon dating of ancient bone using ultrafiltration. Radiocarbon 48, 179-195.

Hillson, S., 2003. Dental Anthropology. Cambridge University Press, Cambridge.

Hoffmann, A., Hublin, J.-J., Hüls, M., Terberger, T., 2011. The Homo aurignaciensis hauseri from Combe-Capelle - a mesolithic burial. J. Hum. Evol. 61, 211-214.

Hublin, J.-J., 1990. Les peuplements paléolithiques de L'Europe: un point de vue paléobiogéographique. In: Farizy, C. (Ed.), Paléolithique moyen récent et Paléolithique supérieur ancien en Europe. Colloque international de Nemours. APRAIF, Nemours, pp. 29-37.

Hublin, J.-J., Bailey, S.E., 2006. Revisiting the last Neandertals. In: Conard, N.J. (Ed.) When Neanderthals and Modern Humans Met. Kerns Verlag, Tuebingen, pp. $105-128$

Hublin, J.-J., Spoor, F., Braun, M., Zonnenveld, F., Condemi, S., 1996. A late Neanderta associated with Upper Palaeolithic artefacts. Nature 381, 224-226.

Huntley, D.J., Baril, M.R., 1997. The K content of the K-feldspars being measured in optical dating or in thermoluminescence dating. Ancient TL 15, 11-13.

Jacobi, R.M., Higham, T.F.G., Bronk Ramsey, C., 2006. AMS radiocarbon dating of Middle and Upper Palaeolithic bone in the British Isles: improved reliability using ultrafiltration. J. Quatern. Sci. 21, 557-573.

Jorïs, O., Fernández, E.A., Weninger, B., 2003. Radiocarbon evidence of the Middle to Upper Palaeolithic transition in south-western Europe. Trabalhos de Prehistória 60, 15-38.

Jorïs, O., Street, M., 2008. At the end of the $14 \mathrm{C}$ time scale-the Middle to Upper Paleolithic Record of western Eurasia. J. Hum. Evol. 55, 782-802.

Keeley, H.C.M., Macphail, R.I., 1981. A Soil Handbook for Archaeologists. Bull. Instit. Archaeol., London, pp. 225-243.

Klaric, L., Guillermin, P., Aubry, T., 2009. Des armatures variées et des modes de productions variables. Réflexions à partir de quelques exemples issus du Gravettien d'Europe occidentale (France, Portugal, Allemagne). Gallia Préhistoire 51, 113-154.

Laignel, B., Quesnel, F., Meyer, R., Bourdillon, C., 1999. Reconstruction of the upper Cretaceous chalks removed by dissolution during the Cenozoic in the western Paris basin. Int. J. Earth Sci. 88, 467-474.

Larue, J.-P., 2008. Tectonic influence on the quaternary drainage evolution on the north-western margin of the French Central Massif: the Creuse valley example. Geomorphology 93, 398-420.

Laville, H., 1972. Paléoclimatologie du Würm ancien en Périgord: Données sédimentologiques. In: Ters, M. (Ed.), Études sur le Quaternaire dans le Monde. INQUA, Paris, pp. 513-518.

Leroi-Gourhan, A., 1958. Études des restes humains fossiles provenant des grottes d'Arcy-sur-Cure. Annls. Paléont 43, 87-148.

Leroyer, C., Leroi-Gourhan, 1983. Problème de Chronologie: le Castelperronien et l'Aurignacien. Bull. Soc. Préhist. Fr. 80, 41-44.

Lévêque, F., 1987. Les gisements castelperroniens de Quincay et de Saint-Césaire: quelques comparaisons préliminaires - Stratigraphie et industrie. In: Préhistoire de Poitou-Charentes, Problèmes actuels. Editions CTHS, Paris, pp. 91-98.

Lévêque, F., 1997. Le Passage du Paléolithique moyen au Paléolithique supérieur: Données stratigraphiques de quelques gisements sous-grotte du sud-ouest. Quaternaire 8, 279-287.

Lévêque, F., Miskovsky, J.C., 1987. Le Castelperronien dans son environnement géologique. L'Anthropologie 37, 369-391.

Lévêque, F., Vandermeersch, B., 1980. Découverte de restes humains dans le niveau Castelperronien à Saint-Césaire (Charente-Maritime). C.R. Acad. Sc. Paris 291, 187-189.

Longin, R., 1971. New method of collagen extraction for radiocarbon dating. Nature $230,241-242$.

Lucas, G., Rigaud, J.P., Simek, J., Soressi, M., 2003. The Châtelperronian of Grotte XVI Cenac-et-Saint-Julien (Dordogne, France). Trabalhos de Arqueologia 33, 289-298. 
Mazière, G., Tixier, J., 1976. Les civilisations du Paléolithique supérieur en Limousin. In: de Lumley, H. (Ed.), La Préhistoire Française. Editions CNRS, Paris, pp. 1281-1296.

Médioni, M.R., Debrand-Passard, M.S., Perna, G., Weecksteen, M.M., 1974. Châtellerault. Carte Géologique de la France a 1/50000. Ministère de l'Industrie et de la Recherche, Service Géologique National, Paris.

Mégnien, C., Mégnien, F., Debrand-Passard, S., 1980. Synthèse Géologique du Bassin de Paris. B.R.G.M, Orléans.

Mellars, P.A., 1989. Major issues in the emergence of modern humans. Curr. Anthropol. 30, 349-385.

Mellars, P.A., 1999. Châtelperronian chronology and the case for Neandertal/Modern human acculturation in Western Europe. In: Stringer, C.B., Barton, R.N.E. Finlayson, J.C. (Eds.), Neanderthals on the Edge. Oxbow Books, Oxford, pp. 33-39.

Mellars, P.A., 2005. The impossible coincidence: a single species model for the origins of modern humans behaviour in Europe. Evol. Anthropol. 14, 12-27.

Mercier, N., Valladas, H., 1994. Thermoluminescence dates for Paleolithic Levant. In: Bar-Yosef, O., Kra, R. (Eds.), Late Quaternary Chronology and Paleoclimate of the Eastern Mediterranean. University of Arizona, Tucson, pp. 13-20.

Mercier, N., Valladas, H., Joron, J.L., Reyss, J.L., Lévêque, F., Vandermeersch, B., 1991. Thermoluminescence dating of the late Neanderthal remains from Saint-Césaire. Nature 351, 701-702.

Montes, R., Sanguino, J. (Eds.), 2001. La Cueva del Pendo. Actuaciones Arqueológicas 1994-2000. Ayuntamiento de Camargo/ Gobierno de Cantabria/Parlamento de Cantabria, Santander.

Morin, E., Tsanova, T., Sirakov, N., Rendu, W., Mallye, J.B., Lévêque, F., 2005. Bone refits in stratified deposits: testing the chronological grain at Saint-Césaire. J. Archaeol. Sci. 32, 1083-1098.

Movius, H.L., 1969. The Chatelperonian in French Archaeology: the evidence of Arcy-sur-Cure. Antiquity 43, 111-123.

Murray, A.S., Marten, R., Johnston, A., Martin, P., 1987. Analysis for naturally occurring radionuclides at environmental concentrations by gamma spectrometry. J. Radioanal. Nucl. Chem. 115, 263-288.

Murray, A.S., Wintle, A.G., 2000. Luminescence dating of quartz using an improved single-aliquot regenerative-dose protocol. Radiat. Meas. 32, 57-73.

Murray, A.S., Wintle, A.G., 2003. The single aliquot regeneration dose protocol: potential for improvements in reliability. Radiat. Meas. 37, 377-381.

Nicod, J., 1994. Paléokarst et paléomorphologies dans le domaine méditerranéen (éléments de reflexion et discussion). Rev. Géogra. Maroc. 16, 309-333.

Nicod, J., 2002. Karst, Palaeogeomorphology, palaeoenvironments. An overview of recent research on French karst (1992-2001). Géomorphologie 3, 253-268.

Olivier, G., Demoulin, F., 1990. Pratique Anthropologique. Ostéologie. Université de Paris VII, Paris.

Olley, J.M., Murray, A.S., Roberts, R.G., 1996. The effects of disequilibria in the uranium and thorium decay chains on burial dose rates in fluvial sediments. Quatern. Geochronol. 15, 751-760.

Pelegrin, J., 1995. Technologie lithique: le Châtelperronien de Roc-de-Combe (Lot) et de La Côte (Dordogne). Cahiers du Quaternaire 20. Editions CNRS, Paris.

Pelegrin, J., Soressi, M., 2007. Le Châtelperronien et ses rapports avec le Moustérien. In: Vandermeersch, B., Maureille, B. (Eds.), Les Néandertaliens: Biologie et cultures. Editions CTHS, Paris, pp. 283-296.

Peresani, M., 2003. Discoid Lithic Technology: Advances and Implications Archaeopress, Oxford. BAR International Series 1120.

Peyrony, D., 1934. La Ferrassie. Préhistoire 3, 1-92.

Peyrony, D., 1936. Le Périgordien et l'Aurignacien. Nouvelles observations. Bull. Soc Préhist. Fr. 33, 616-619.

Peyrony, D., 1948. Une mise au point au sujet de l'industrie de l'abri Audi et de celle de Châtelperron. Bull. Soc. Préhist. Fr. 45, 34-35.

Pradel, L., 1952. La grotte périgordienne et aurignacienne de Fontenioux commune de Saint-Pierre-de-Maillé (Vienne). Bull. Soc. Préhist. Fr. 49, 413-432.

Pradel, L., 1961. La Grotte des Cottés, commune de Saint-Pierre-de Maillé (Vienne). L'Anthropologie 65, 229-270.

Primault, J., 2003. Exploitation et diffusion des silex de la région du Grand-Pressigny au Paléolithique. Ph.D. Dissertation, University of Nanterre - Paris X.

Reimer, P.J., Baillie, M.G.L., Bard, E., Bayliss, A., Beck, J.W., Blackwell, P.G., Bronk Ramsey, C., Buck, C.E., Burr, G., Edwards, R.L., Friedrich, M., Grootes, P.M Guilderson, T.P., Hajdas, I., Heaton, T.J., Hogg, A.G., Hughen, K.A., Kaiser, K.F., Kromer, B., McCormac, F.G., Manning, S.W., Reimer, R.W., Richards, D.A. Southon, J., Turney, C.S.M., van der Plicht, J., Weyhenmeyer, C., 2009. IntCal09 and Marine09 radiocarbon age calibration curves, 0-50,000 years cal BP. Radiocarbon 51, 1111-1150.

Rigaud, J.P., 1996. L'émergence du Paléolithique supérieur en Europe occidentale. Le Rôle du Castelperronien. In: Bar-Yoseph, O., Cavalli-Sforza, L., March, R. Piperno, M. (Eds.), The Lower and Middle Palaeolithic. ABACO, Forli, pp. 219-223.

Rigaud, J.P., 2001. A propos de la contemporanéité du Castelperronien et de l'Aurignacien ancien dans le nord-est de l'Aquitaine: une révision des données et ses implications. Trabalhos de Arqueologia 17, 61-68.

Roussel, M., Sorressi, M., 2010. La Grande Roche de la Plématrie à Quinçay (Vienne). L'évolution du Châtelperronien revisitée. In: Buisson-Cattil, J., Primault, J. (Eds.), Préhistoire entre Vienne et Charente. Hommes et sociétés du Paléolithique. 25 ans d'archéologie préhistorique en Poitou-Charentes. Association des Publications Chauvinoises, Chauvigny, pp. 203-220.

Smith, B.H., 1984. Patterns of molar wear in hunter-gatherers and agriculturalists Am. J. Phys. Anthropol. 6, 39-56.

Smith, B.H. 1991. Standards of Human Tooth Formation and Dental Age Assessment In: Kelly, M.A., Larsen, C.S. (Eds.), Advances in Dental Anthropology. Wiley-Liss, New York, pp. 143-168.
Sonneville-Bordes, D., 1989. Préface. Bull. Soc. Préhist. Ariège 44, 5-17.

Sonneville-Bordes, D., 1960. A propos du Périgordien I du Périgord. Bull. Soc. Préhist. Fr. 57, 536-537.

Sonneville-Bordes, D., 1966. L'évolution du Paléolithique supérieur en Europe Occidentale et sa signification. Bull. Soc. Préhist. Fr. 63, 3-34.

Sonneville-Bordes, D., 1972. Environnement et culture de l'homme du Périgordien ancien dans le Sud-Ouest de la France; données récentes. In: Origine de l'homme moderne (écologie et conservation). Unesco, Paris, pp. 141-146.

Soressi, M., 2002. Le Moustérien de tradition acheuléenne du sud-ouest de la France. Discussion sur la signification du faciès à partir de l'étude comparée de quatre sites: Pech-de-l'Azé I, Le Moustier, La Rochette et la Grotte XVI. Ph.D. Dissertation, University of Bordeaux I.

Soressi, M., 2010. La Roche-à-Pierrot à Saint-Césaire (Charente-Maritime) Nouvelles données sur l'industrie lithique du Châtelperronien. In: BuissonCattil, J., Primault, J. (Eds.), Préhistoire entre Vienne et Charente. Hommes et sociétés du Paléolithique. 25 ans d'archéologie préhistorique en Poitou-Charentes. Association des Publications Chauvinoises, Chauvigny, pp. 191-202.

Soressi, M., Roussel, M., Rendu, W., Primault, J., Rigaud, S., Texier, J.P., Richter, D., Talamo, S., Ploquin, F., Larmignat, B., Tavormina, C., Hublin, J.J., 2010. Les Cottés (Vienne). Nouveaux travaux sur l'un des gisements de référence pour la transition Paléolithique moyen/supérieur. In: Buisson-Cattil, J., Primault, J. (Eds.), Préhistoire entre Vienne et Charente. Hommes et sociétés du Paléolithique. 25 ans d'archéologie préhistorique en Poitou-Charentes. Association des Publications Chauvinoises, Chauvigny, pp. 221-234.

Spooner, N.A., 1994. The anomalous fading of infrared-stimulated luminescence from feldspars. Radiat. Meas. 23, 625-632.

Stoops, G., 2003. Guidelines for Analysis and Description of Soil Regolit Thin Sections. Soil Science Society of America, Madison, Wisconsin.

Stuiver, M., Polach, H.A., 1977. Discussion: Reporting of ${ }^{14} \mathrm{C}$ data. Radiocarbon 19, 355-363.

Szmidt, C.C., Normand, C., Burr, G.S., Hodgins, G.W.L., LaMotta, S., 2010. AMS ${ }^{14}$ C dating the Protoaurignacian/Early Aurignacian of Isturitz, France. Implications for Neanderthal-modern human interaction and the timing of technical and cultural innovations in Europe. J. Archaeol. Sci. 37, 758-768.

Texier, J.P., 2009. Histoire géologique des sites préhistoriques classiques du Périgord: une vision actualisée. La Micoque, la grotte Vauffrey, le Pech de l'Azé I et II, La Ferrassie, l'abri Castanet, Le Flageolet, Laugerie-Haute. Editions CTHS, Paris.

Thiel, C., Buylaert, J.P., Murray, A.S., Terhorst, B., Hofer, I., Tsukamoto, S., Frechen, M., 2011. Luminescence dating of the Stratzing loess profile (Austria) - Testing the potential of an elevated temperature post-IR IRSL protocol. Quatern. Int. 234, $23-31$.

Thomsen, K.J., Murray, A.S., Jain, M., 2011. Stability of IRSL signals from sedimentary K-feldspar samples. Geochronometria 38, 1-13.

Thomsen, K.J., Murray, A.S., Jain, M., Bøtter-Jensen, L., 2008. Laboratory fading rates of various luminescence signals from feldspar-rich sediment extracts. Radiat. Meas. 43, 1474-1486.

Turner II, C.G., Nichol, C.R., Scott, G.R., 1991. Scoring procedures for key morphological traits of the permanent dentition: the Arizona State University dental anthropology system. In: Kelley, M., Larsen, C. (Eds.), Advances in Dental Anthropology. Wiley Liss, New York, pp. 13-31.

Van der Plicht, J., Beck, J.W., Bard, E., Baillie, M.G.L., Blackwell, P.G., Buck, C.E., Friedrich, M., Guilderson, T.P., Hughen, K.A., Kromer, B., McCormac, F.G., Bronk Ramsey, C., Reimer, P.J., Reimer, R.W., Remmele, S., Richards, D.A., Southon, J.R., Stuiver, M., Weyhenmeyer, C.E., 2004. NotCal04-Comparison/Calibration ${ }^{14} \mathrm{C}$ records 26-50 cal kyr BP. Radiocarbon 46, 1225-1238.

Vandermeersch, B., 1984. A propos de la découverte du squelette Néandertalien. Bull. Mém. Soc. Anthropol. Paris 1, pp. 191-196.

Vieillevignes, E., Bourguignon, L., Ortega, I., Guibert, P., 2008. Analyse croisée des données chronologiques et des industries lithiques dans le grand Sud-ouest de la France (OIS 10 à 3). Paléo 20, 145-166.

Voinchet, P., Despriée, J., Tissoux, H., Falguéres, C., Bahain, J.-J., Gageonnet, R., Dolo, J.M. 2010. ESR chronology of alluvial deposits and first human settlements of the middle Loire basin (Region Centre, France). Quatern. Geochronol. 5, 381-384.

Weninger, B., Jöris, O., 2008. A ${ }^{14} \mathrm{C}$ age calibration curve for the last $60 \mathrm{ka}$ : the Greenland-Hulu U/Th time-scale and its impact on understanding the middle to upper Paleolithic transition in Western Eurasia. J. Hum. Evol. 55, 772-781.

White, R., 2001. Personal ornaments from the Grotte du Renne at Arcy-sur-Cure. Athena Rev. 2, 41-46.

Zilhão, J., 2001. Anatomically Archaic, Behaviorally Modern: The Last Neanderthals and their Destiny. Stichting Nederlands. Museum voor Anthropologie en Praehistoriae, Amsterdam.

Zilhão, J., 2006. Neandertals and moderns mixed, and it matters. Evol. Anthropol. $15,183-195$

Zilhão, J., 2007. The emergence of ornaments and art: an archaeological perspective on the origins of behavioral "modernity." J. Archaeol. Res. 15, 1-54.

Zilhão, J., d'Errico, F., 2003. The Chronology of the Aurignacian and transitional technocomplexes. Where do we stand? Trabalhos de Arqueologia 33, 313-349.

Zilhão, J., d'Errico, F., Bordes, J.-G., Lenoble, A., Texier, J.-P., Rigaud, J.-P., 2006. Analysis of Aurignacian interstratification at the Châtelperronian-type site and implications for the behavioral modernity of Neandertals. Proc. Natl. Acad. Sci. 103 (33), 12643-12648.

Zilhão, J., Davis, S.J.M., Duarte, C., Soares, A.M.M., Steier, P., Wild, E., 2009. Pego do Diabo (Loures, Portugal): dating the emergence of anatomical modernity in Westernmost Eurasia. PLoS ONE 5 (1) doi:10.1371/journal.pone.0008880. 